\title{
Spatial and Security Organisation of Court Buildings: An Assessment of Selected High Court Buildings in Nigeria
}

\author{
Olusola Oladapo Makinde (1) \\ Department of Architecture, Ladoke Akintola University of Technology, Ogbomoso, Nigeria \\ E-mail: makindeolusola2012@yahoo.com
}

Received: 15 July 2019; Revised: 2 November 2020; Accepted: 23 December 2020

\begin{abstract}
Within the context of functional efficiency, this study assesses the spatial organisation and security of court building in Southwest Nigeria as a panacea to a design proposal for an ideal high court building. To achieve this, fifteen structural parameters were employed for measuring efficiency. These are spaces organisation, spaces standard, structural fitness, communication, noise, environmental cleanliness, building layout, privacy, visual form, security, parking spaces, acoustics system, circulation pattern and spaces allocation. Towards the realisation of these objectives, both primary and secondary data were collected. The primary data employed include field measurement, personal observation of court proceedings, oral interview and administration of 290 questionnaires to court personnel, and other court participants to elicit information on the effects of adequate security and spatial organisation. The merits and demerits of the studied area along with their photographs were also documented. The information from the questionnaires was analysed using frequency distribution tables, simple percentages and relative important index. Results revealed that the court buildings were largely inadequate to space organisation and space standard. The result shows that $90 \%$ of the respondents agreed that poor spatial organisation, inadequate security, and poor landscaping are the major shortcomings inhibiting the efficiency of court buildings, while $80 \%$ agreed that the existing structures are satisfactory only in the areas of environmental cleanliness and communication within the courtrooms. Hence, the study presented useful suggestions and recommendations.
\end{abstract}

Keywords: court buildings, spatial organisation, facilities assessment, spatial planning

\section{Introduction}

Looking into the location and physical setting of existing high courts of justice buildings in Nigeria, one could see that there are a series of problems, which affect the institution in performing its important functions adequately. Some of the problems include spaces for personnel and equipment, poor space arrangement, security, circulation problem, ventilation, lighting, noise and glare effect. What is obtained in Nigeria now is more or less a qualitative judicial problem rather than quantitative [1] The United Nations [2] recognised that cities in a developing country need an increase of 10-12 courts per 280 cases weekly. Based on this, Nigeria cities will need a 'standard court complex' that is adequate to handle the myriad of cases before it. These needs have never been met because of the financial problems, theland ownership issues, the cost of building materials and the lack of infrastructural amenities. It is worrisome to

Copyright (C2020 Olusola Oladapo Makinde

DOI: https://doi.org/10.37256/gbce. 112020539

This is an open-access article distributed under a CC BY license

(Creative Commons Attribution 4.0 International License)

https://creativecommons.org/licenses/by/4.0/ 
note at this junction that the existing court buildings in our cities are grossly substandard and unbefitting. Given the above observation, a high court complex should be a place where people can work in an atmosphere conducive for high productivity and the welfare of workers is to be enhanced.

Mulcahy [3] looked at the interface between the design of courtrooms and the concept of participatory justice. This study argued that understanding the factors which determine the internal design of the courtroom is vital to a wider and more understanding of judge capability. The use of space in the courtroom has changed significantly since custombuilt courthouses first appeared, and these changes often reflect the struggles for territory. It concluded that public space within the court has come to be associated with danger and the surveillance of those who come to observe the process of judge-craft an imperative [3].

According to Makinde [4], most of the existing court buildings in Nigeria have grossly inadequate functional spaces, high-security porosity and poor organisation of spaces which affected the efficiency and functionality of the complex. The study, therefore, will assess the security and space organisation of high court buildings in some selected towns in southwest Nigeria and propose a more comprehensive, functional and exhibit the cultural heritage of the Yoruba's and also that will symbolize equity and equality, tranquillity and peace for the town. The need for this assessment, therefore, came out of the following premises that: It it will reveal the true image of Nigeria High Court building complexes in terms of their level of security and spatial organisation of spaces; and it will help in making necessary and urgent changes in the present set up in our existing court complexes and also help in avoiding these problems from any other proposed court building in Nigeria.

This study assesses the security and spatial organisation of some selected court building, to make necessary recommendations. The specific objectives of the study, therefore, include: to examine the present security condition in Nigeria high court building; to appraise the level of satisfaction of acoustic consideration in our high court building; and to assess the level of satisfaction of communication and spatial organisation pattern in the court building.

This study, therefore, asked some research questions that comprised: (1) What is the level of security in our high court building? (2) What are the effects of poor spatial organisation in our court building? and What are the levels of acoustic consideration in court buildings? Meanwhile, the research hypotheses include: the level of security in Nigeria high court buildings is not satisfactory, and the level of acoustic consideration in our courtroom is not satisfactory. The study assesses the security and spatial organisation of some selected high court building in Nigeria using some indicators. These indicators include adequate security, circulation and space pattern, building layout, privacy, adequate parking space, pollution control, communication and special pattern within the courtroom, accessibility with other departments, adequate pedestrian circulation, symbolic/visual form, environmental cleanliness, structural fitness, and acoustic consideration. Having in mind to have a complex that is environmentally friendly and conducive enough to promote the efficient administration of justice.

This study aims at filling the gap in the literature, by exploring some relations between these courthouses in South West Nigeria and the locations in which it takes place, its functional requirements imposed by a transformation agenda that is taking place in the judicial system, in a context of functional efficiency and spatial organisation, the study areas comprises the high court of justice, Ibadan; Ikeja high court complex Lagos State; the state high court justice, Osogbo; the high court of justice, Ogun State; and Ile-Ife high court complex, Osun State.

\section{Literature review}

Law is an instrument of social stratification, used to curtail the rights of the individuals in society. Without law, government manifestation would be impossible [5]. In every society, no matter how rudimentary, a certain form of law must operate. This is the basis of the legal maxim 'Ubi Societas Ubi jus' (where there is society, there is the law). When these laws were made, a system of civil and criminal dispensation of justice is in the cradle. The Lord in the Garden of Eden promulgated the first law. The Garden of Eden is the first courthouse and this is where the first judgment took place [6]. This necessitated the establishment of courts to interpret the law and apply it to the facts of specific cases. If every man were free to disregard any rule of society that he disliked or found inconvenient, Anarchy and brute force would prevail, or if a citizen commits a crime, other persons offended by this conduct could take the law into their hands and proceed to punish him according to their controlled discretion which might result into physical violence 
and insurgence [7]. All these have given credence to the establishment of courts as an essential part of the machinery of government to settle the dispute between citizens, between citizens and government, and between governments in all civilised nations of the world [8]. Like all human societies that are undergoing vast economic, industrial and social changes, justice has grown from a casual thing into a process of dignity and great technical intricacy, and consequently requires complex buildings to accommodate its myriad dispositions [9, 10].

A distinguishing factor between man and animal is man's ability to organise and conduct themselves within some set of rules and regulations in a given society [11]. Man can recognise his right, bounds the right of another person and that of the state. He is also able to avoid going beyond his bounds. Therefore, it follows that in every society there must be a body of rule and authority to enforce them [12]. It is the authority that determines whether a rule has been broken, who broke it and what punishment (if any) such person or persons deserves. Where the legal body comprises all the persons living in a country, its rules are called laws, and the bodies which administer the laws are called courts of justice, under the judiciary which is the third in the arm of government after the executive and legislature [13].

The importance of court statue cannot be overemphasised, which is known as 'ubi remedium' in Latin, simply shows the significance of justice in law court pictorially. The statue shows a woman blindfolded, carrying a balance on one hand and a sword on the other hand (see Figure 1). That is always represented by a woman, to bring a touch of feminist to justice. Unlike masculinity which may have no mercy in judgement even when there is a sign of impartiality. It shows that the law is no respecter of persons [7]. The balance in her hand is a sign of judgment which signifies the process of law, it, therefore, means that the individual or group will be weighed on a scale to see if they are found wanting. However, the sword on the other hand simply signifies the act of punishment. In summary, when a convict is weighed on the scale, if he is found wanting, the sword of Damocles will fall on him [5].

For effectiveness, the courthouse has to be defined and inscribed in space, architecturally and geographically [14]. The concept of a courthouse as a specific kind of building for determination of cases is a contemporary development [3]. According to Branco [15], a courthouse is a building specifically for delivering justice. Therefore, the courthouses edifices, through their specific complex internal organisation and architectures, offer not only a space for the process of justice and law, yet also outline setting through which people can essentially experience judicial processes [14, 16, 17]. Courthouse architecture and planning give a legitimate discourse to appropriate space and hence create a context, a structure, a distinct and a symbolic place (that is courthouse building and the courtroom), where the practice and state of the trial, the judicial procedure, and mainly judicial formal procedure occur and performed devoid of being disturbed by the external daily life. Judicial rituals and judicial buildings are entangled, and it is this arrangement that acknowledges authority to the judicial institute and legality to the judicial pronouncement $[10,18]$.

According to Spaulding [19], the conception of the due process of law, with its procedures and rituals, is itself closely and relatively connected to the design, location, and usage of the law's houses. And that becomes particularly important when we consider the comfortability and functionality of workplaces for court professionals and public areas to court users [20]. The standard continues to be the duplication of a (crudely) unchanged architectural pattern, essentially in terms of the courtroom's layout, in addition to the internal arrangement of the courthouse building [4, 21].

Nevertheless, such an arrangement is being extremely contested, particularly by court professionals (judges and prosecutors), principally the lack of suitable hearing rooms to conduct case hearings and conferences involving clients. Unfortunately, though, court buildings do not play an important role in most law and courts research; and where the courthouse has been considered, writers often assume the need for a ritualized adjudicative process within a certain kind of building, usually an imposing one [10]. And so far, to evaluate the judiciary's built environment is very significant, as it exposes the values and the social practices, governing ideologies that uphold the judiciary [15, 22].

The improvement of courthouse architecture in Nigeria as a professional field of proficiency not only had a substantial effect on the institutionalisation of the judiciary system, but it also helped the judiciary system gain legitimacy $[4,23]$. Therefore, the courthouses are a predominantly elaborate structure [24], demanding different sets of rooms, and complex circulation schemes for judges, prosecutors, court officials, parties, experts, defendants (several of whom may be in custody), witnesses and victims (a number of them rather exposed), and the general public. Also, suitability to the information and communication equipment and they need to accommodate diverse social groups and diverse expectations. All this need efficacy, efficiency and rationalisation of resources (human, procedural, material and budgetary provision) brought in by the new public administration [5].

When citizens enter a courthouse building, they usually feel they have walked into a strange world [25]. Moreover, 
the physical architecture and environment of a courthouse can either validate a sensitivity to the requirements of the citizens or add immensely to the ordeal which a court experience can signify [26]. Hence, being asked to speak to an unfamiliar person (like experts and judges) about traumatizing proceedings while sitting on furniture not made for their sizes and proportions; at times near a violent person, thereby adding to an uncomfortable atmosphere, can be distressing and painful $[27,28]$. What happens most of the times is impartiality between the rigidity, the sensitivity of the issues handled and unfriendliness of the courts' environment and spaces.

Thus, one of today's styles is an architectural design which seeks to be less magnificent and more welcoming for the public, with structures providing easy access to court users. This may be an indication of the approach that the concept of justice has developed [25], in the realm of a comprehensive change of the social configurations. It is vital that plans to renovate or construct courthouse amenities are planned and design to provide a high-quality justice, which shows that the expectations and perception of the users have to be taken into consideration [29]. According to Commaille [30], considering such expectations would lead to the characterisation of new forms and practices of law buildings and courthouse architecture that enhance a new development in which citizens can fully contribute, thus enhancing and improving the legality of dispute determination [10].

There is a great need for an in-depth examination of how current designs of courthouse building spaces in Nigeria may be deficient and lacking, particularly in terms of how the court participant experiences in their environment, and how they might be improved.

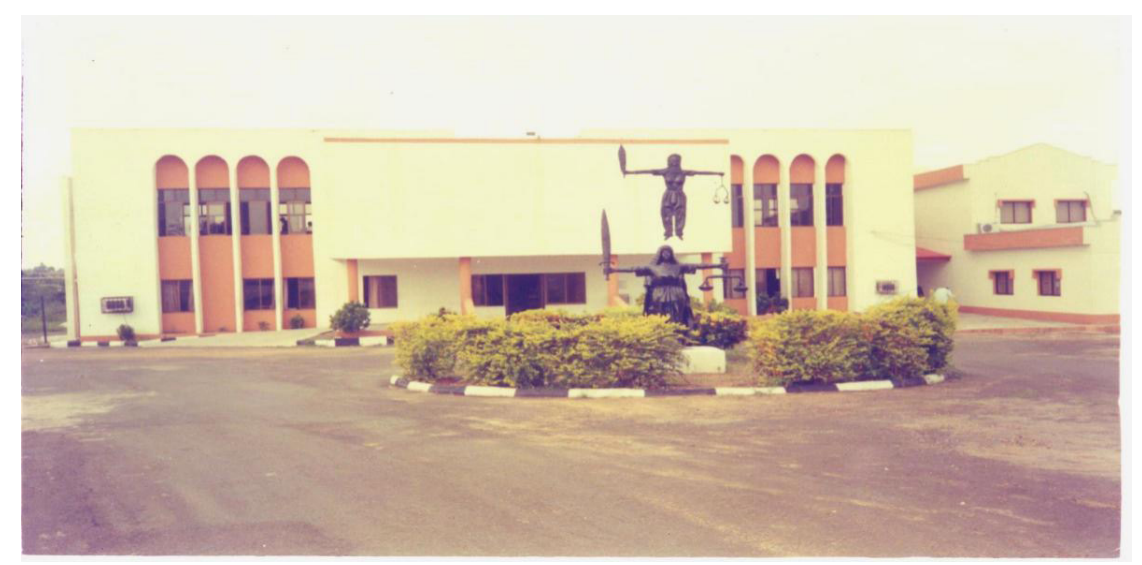

Source: by the Author, 2018

Figure 1. Court statue

\section{Research methods, findings and results}

\subsection{Methodology}

Towards the realisation of these objectives, both primary and secondary data were collected.

\subsubsection{Collection of primary data}

This was done through the administration of a designed questionnaire to five high courts building under review. For the effectiveness of the questionnaire administration, the court premises were divided into various units, which are: administrative unit, registry unit, cash office or adult/account department, court room, library/archives and others. Since there are various units within the court premises, a systematic random sampling method was adopted in the administration of questionnaires. To achieve this, $50 \%$ of the total number of the staff in each unit were taken as sample.

\subsubsection{Collection of secondary data}

Different kinds of information were obtained from the staff and other participants of the high courts under review. 
Such information includes the security situation in the premises, the site planning in the premises, space patterns, symbolic meaning of the building, circulation pattern, courtroom arrangement, hearing, visual quality, movement pattern in the courtroom, document transfer and other associated problems. Relevant information was also obtained from journals articles, library and the internet on the proper way of designing a functional high court. This was carried out to determine the security and spatial organisation situation of various high court building and how these situations will be rectified in the subsequent design or study.

\subsubsection{Analysis of collected data}

Data collected were analysed by the use of relevant statistical method and integration of literature review and reconnaissance survey.

\section{Case studies}

A careful analysis of Nigerian courts buildings that comprise the high court complex, Ibadan; Ikeja high court complex Lagos state; the state high court justice complex, Osogbo; the high court of justice complex, Ogun State; and Ile-Ife high court complex, Osun State as case studies reveals the major techniques employed to satisfy the requirements of a functional courthouse, as well as to find the problems bedevilling such buildings and postulates solutions to such problems in the proposed design. These case studies are outlines as follows based upon the primary issues necessary in the design of the courthouse.

\subsection{Case study one: The high court of justice, Ibadan}

The year of completion was in 1985 and it is located in Ring Road, Ibadan. The high court is in two phases, and it comprises 15 courtroom complexes. The complexes houses: the high courts of Ibadan; an appeal court; auxiliary offices; accommodation for the police and the cell.

\subsubsection{Site planning}

The site is over $51 / 2$ acres and has a gentle slope to the northeast and a sharp fall northwest, near the western boundary. The main entrance is from the main road to an access road. Entrance to the site leads directly to the public car park but there is no direct route from the public car park to the courtrooms. The public car park is not well defined. The road to the judge's car park is from the ground floor to the left side of the complex into the courtyard from which the carports of the judges are. This is under their chambers and the library. The site planning is such that the direction of approach to the buildings does not make one's way to either the courtroom or the administrative areas obvious, causing confusions to public users. This illustration is shown in Figure 2.

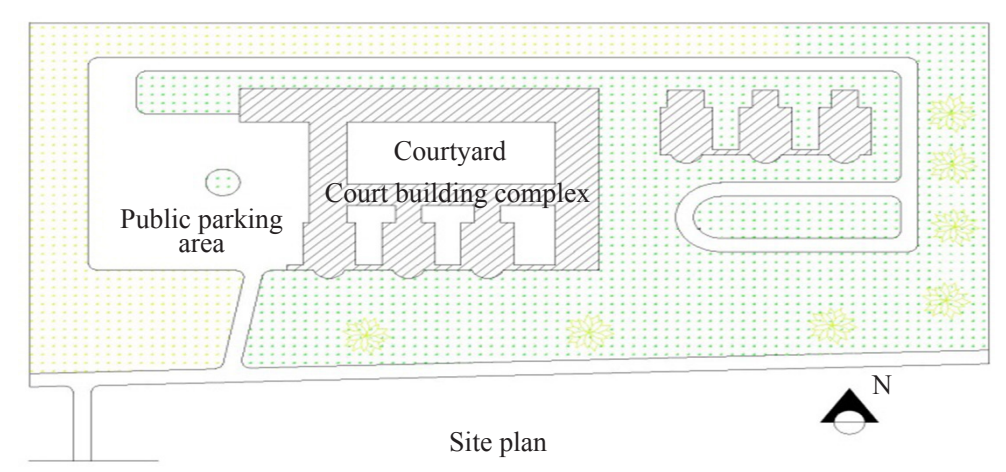

Source: Authors field survey, 2018

Figure 2. Site plan 


\subsubsection{Symbolic meaning}

The high court complex is set on a hill and its towers seem to dominate the landscape. Though the complex is imposing at a glance, it, however, looks more like an office complex or government ministry than a court complex. Hence, we noticed a situation in which though the complex is imposing, yet it does not convey the symbolic meaning of a courthouse. There is also nothing about the exterior of the complex that suggests that the complex is a high court.

\subsubsection{Space patterns}

The planning of the court complex is based on courtyard arrangements and the separation of the judicial from the administrative function is obvious. The courts are a floor higher than the rest of the complex, which make them visually distinct. Hence, we see a dominance of space by the courtrooms. The fifteen courts are double volume with galleries. Hence, three blocks linked together as courtrooms. Behind these is a three-storey building that serves as the registry and general administrative. A two-storey block raised on columns joins the courtrooms at the back and this accommodates the library, judge's common rooms and the administrative spaces that require central access, while the ground floor serves as the car park for the judges and senior staffs (see Figure 3).

\subsubsection{Circulation patterns}

Even though separation of circulation is achieved within the complex itself, there are still more defects in the circulatory patterns. One obvious defect is the non-existence of the main entrance that is necessary for a public building. There is also no obvious entrance to the courtrooms or the administrative area, therefore confusing public users. The place that looks like an entrance from the car park is marked "NO ENTRY" because it is supposed to be the private entrance for the judges, which is inadequate because of the lack of security measures. A vertical circulation system is used at the courtrooms and the judge's chambers. There is a private staircase for use by prisoners, court staff and technical staff that led directly into the courtroom on each floor. There are public staircases for each courtroom block, which led to the courtroom. Another defect in the circulation pattern is the long-distance separating registry from the courtroom. However, the courtyard arrangement aids circulation. A ramp is also provided to create a normal ordered environment that embraces the qualities of dignity, self-respect and control which made more interesting by a careful internal balance of symmetrical plan forms, horizontal and vertical directional development and natural build-up areas that excite and attract the users (see Figure 3).
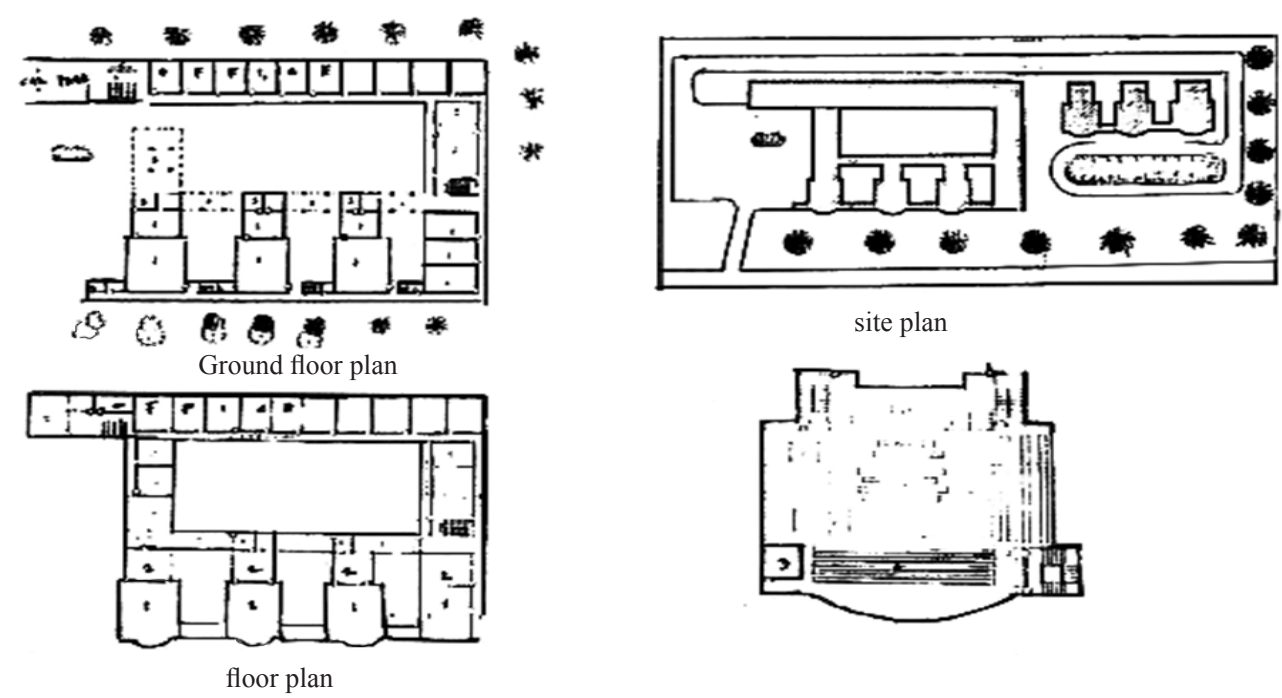

site plan

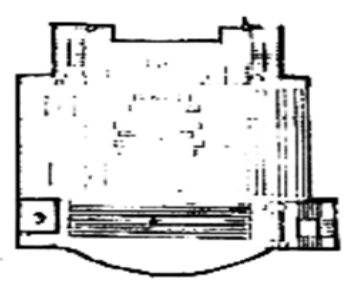

Source: Author's creation, 2018

Figure 3. Building plan, site plan and Ibadan high court 


\subsubsection{Courtroom arrangements}

The internal arrangements of the courtrooms are fair in terms of the position of the dock, witness box, the bench, clerk's desk and lawyers seating. The courtrooms are double volume with a gallery provided as additional sitting for spectators. However, the positioning of the dock is such that the spectators in the gallery cannot have a good view of whoever is there. Another problem with the courtrooms is that the entrances lobby is too small. There is also inadequate provision for waiting and circulation of prisoners. This is as shown in Figure 4.

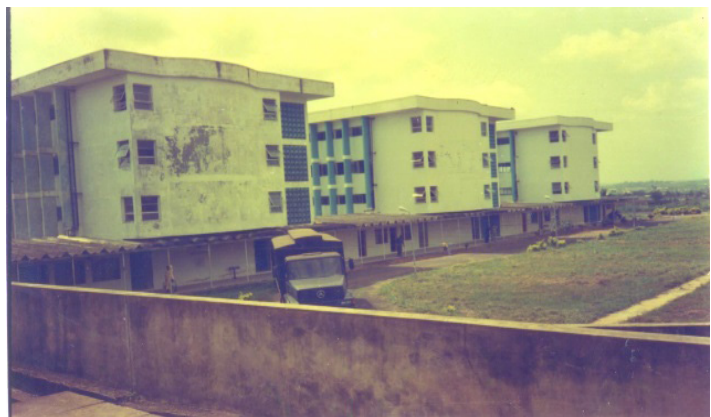

(a) Vehicle position ready to take the accused person away

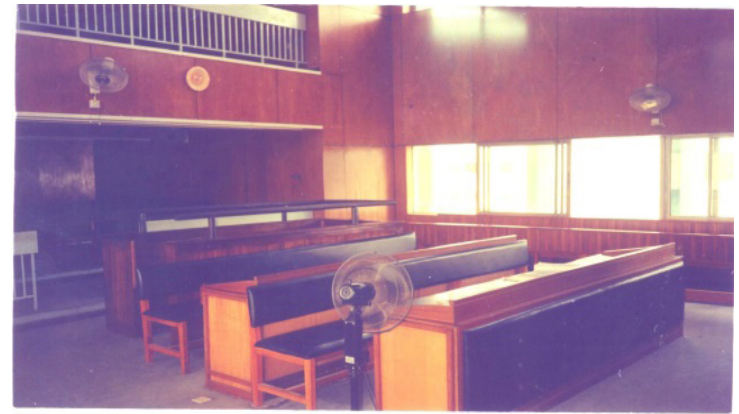

(b) Acousticsmaterials for wall and shows spectators gallery

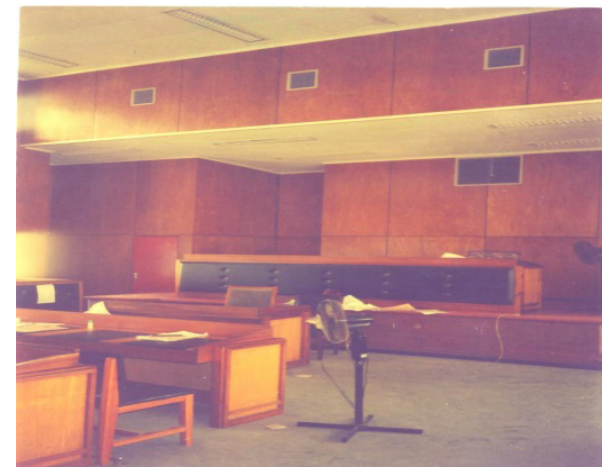

(c) Judge sitting area. Ceiling is cover with acoustics materials

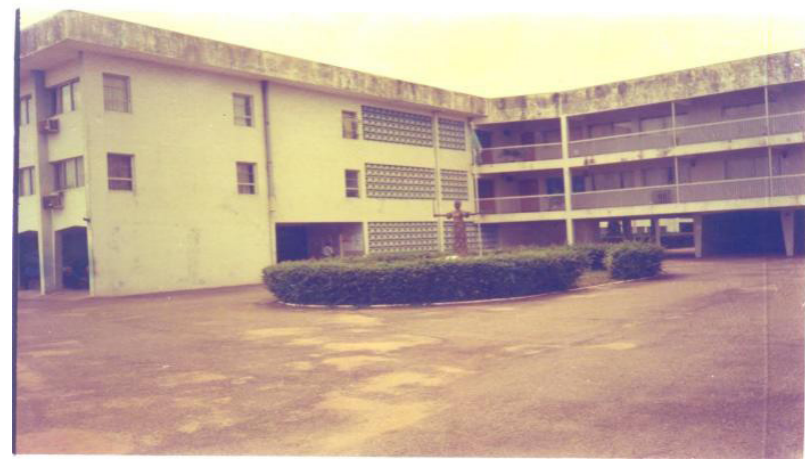

(d) Entrance area and parking area for staff

Figure 4. Courtroom internal arrangements and external landscape

\subsection{Case study two: Ikeja high court complex Lagos State}

The year of completion of the old building was in 1972 and New Chief Judge's Court was in 1995 and it is located at Old Secretariat, Ikeja, Lagos. The architects is D.D Cray of Lagos state works for the management board. He designs the Chief Judge's court. The project is located at the old secretariat in Ikeja where the complex buildings were located and were on two adjacent plots which house the magistrate and high courts. There were two court buildings, the old one completed in 1972 and a new chief Judge's court that was completed in 1995. The courts were developed in phases. Presently, a new high court building is under construction, which was located not far from the present high court buildings.

\subsubsection{Site planning}

In line with the above, there seems to be no deliberate attempt to articulate a good site plan. The piecemeal approach used for the development of the individual buildings as opposed to a holistic approach to the whole development on site seems to account for this. The parking spaces are inadequate neither were they well layout. There is also no separate pedestrian circulation. Though some lines were drawn on the tarred site to guide parking, their layout 
often causes traffic problems, also because of the poor layout of the buildings, there is the need to write inscriptions to restrict parking in certain places (see Figure 5).

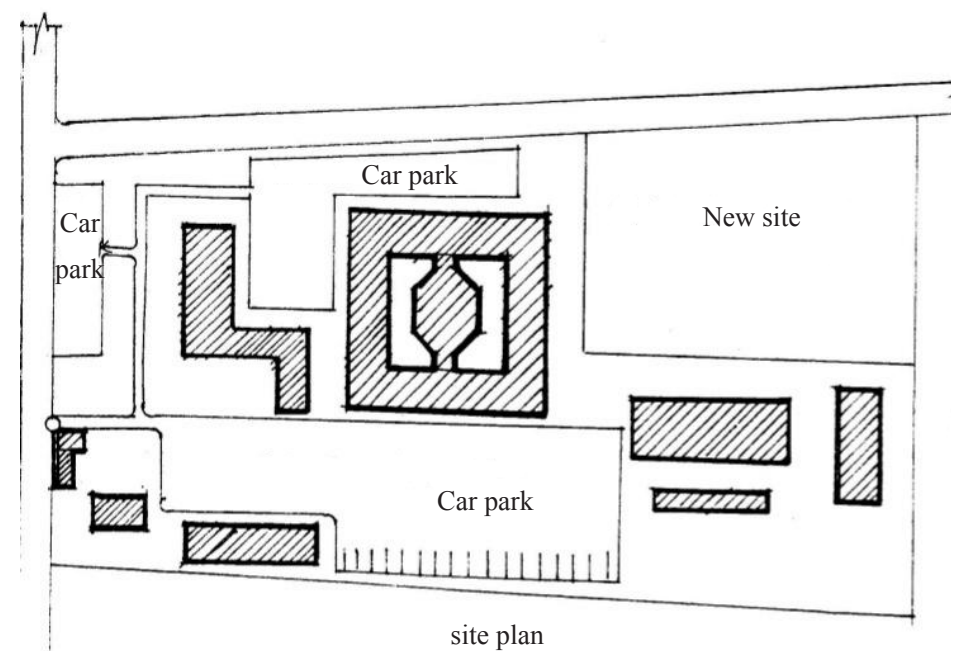

Figure 5. Site plan of Ikeja high court complex Lagos State

\subsubsection{Symbolic meaning}

The old high court building is a long narrow building that cannot be seen from the road. Even when one enters the premises, it is only the end elevation that is visible. Coming close to the building, there is nothing that suggests that it is a formal or government building or even a courthouse. The overall outlook of the building is dull and unexciting even with its aluminium sun breakers on the courtroom floor and no prominent entry. The building, therefore, does not carry any meaning as a courthouse. The new chief judge's court, on the other hand, has a formal look but it can only be a pass for any other institutional or office building than for a courthouse. The facade has nothing to suggest it is a courthouse.

\subsubsection{Space patterns}

The old high court building is with a double banking arrangement of rooms along the corridor. The lower floor serves administrative function while the upper floor judicial ones. The lower floor contains the library, the registry, and other auxiliary facilities while the upper floor contains six courtrooms together with the judge's chambers and judge's secretary offices. Hence, we noticed a differentiation of function by the location of spaces. The new chief judge's court is planned in a courtyard arrangement. The ground floor contains the offices and other administrative function and the chief judge's garage. The upper floor contains the chief judge's court and chambers including the courts and chambers for two other judges. It also contains the probate registry, conference room and offices to the chief registrar and other administrative staff. The library is octagonal and is set right at the centre of the courtyard, indicating another differentiation in space based on function. The library whose function is somehow different from that of the other spaces has a different shape; though there is a differentiation in spaces, there is however a fault in the disposition of the spaces because some related space is placed far apart (see Figure 6). 


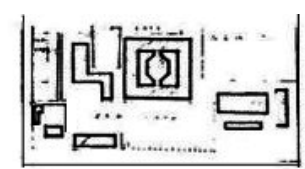

Site plan
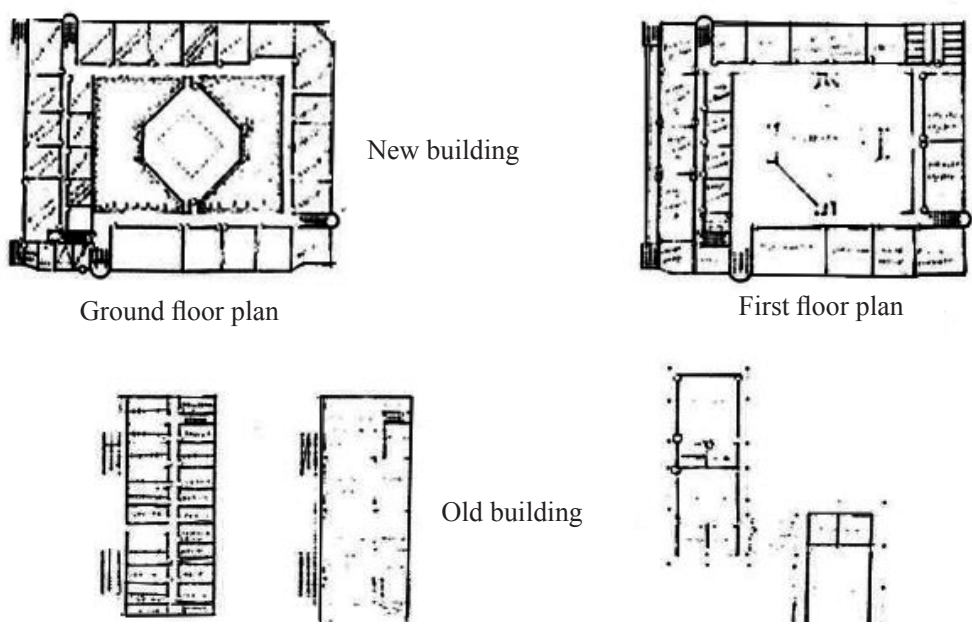

Old building

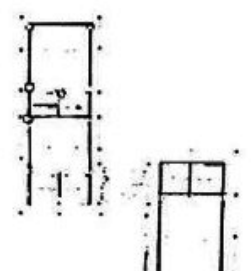

Figure 6. Building plan, site plan and Ikeja high court complex

\subsubsection{Circulation patterns}

There are some very obvious problems with the circulation pattern of the old high court building. The entry that is visible when approaching the building is the judges and staff entrances but not the main entrance. Two narrow 1.3-meter wide straight flight staircases lead to the courtroom floor. This is too narrow considering that there are six courtrooms on the floor. A horizontal circulation system is used for the courtrooms and judge's chambers. The corridors are generally long, narrow and poorly lighted. The aluminium sun breakers provide lighting for the courtroom's corridor, but the judge's corridors, as well as the staff's corridor downstairs, are poorly lighted. There is good circulation in the new court building because of the courtyard. The chief judge parking in the garage has a private staircase leading to his chamber. However, there is no provision for the other judges. The entrance to the library is only from the ground floor; hence, this increases retrieval time for other departments. Another problem is the fact that the judge's circulation is the same as that of the defendants in custody, which is a security risk. The cells for the accused person are located by the gate side, thereby constituting a security lapse (see Figure 6). Figure 7 illustrated the undefined car park area and the scatter courthouses in one of the study areas.

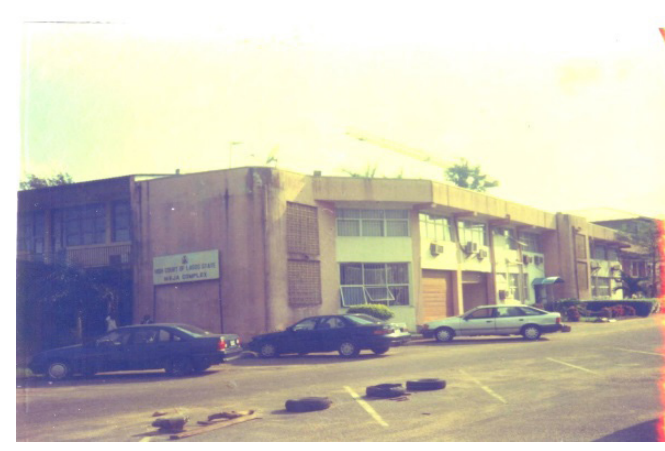

(a) Undefined car park area

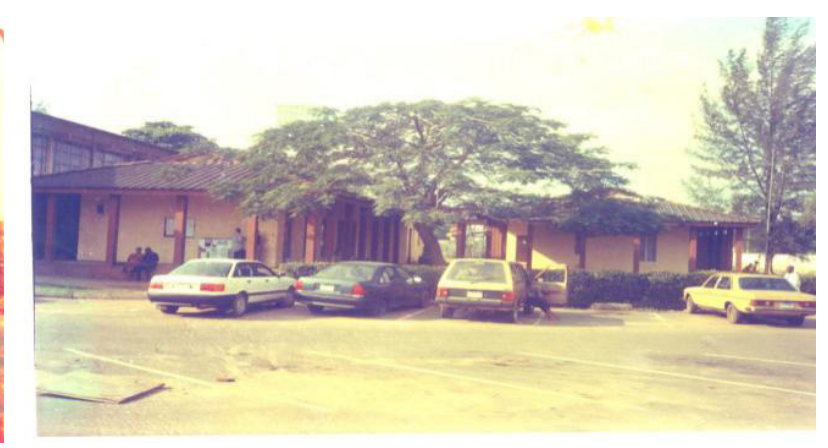

(b) Scatter courthouses

Figure 7. Undefined car park area and the scatter courthouses 


\subsection{Case study three: The state high court justice, Osogbo}

The high court complex is located in Osogbo. It consists of an existing court building and a newly added one. The old building was completed in 1980 and a new high court building complex was completed in 1993. The old building has 3 courtrooms, and the new building has 2 high courtrooms, a makeshift library, a conference room and other administrative offices.

\subsubsection{Site plans}

There seems to be a deliberate attempt to articulate a good site plan, with the parking spaces being well laid out, equipped with separate pedestrian circulation. Florals were used professionally especially in reaction to the new high court complex (see Figure 8 and Figure 9).

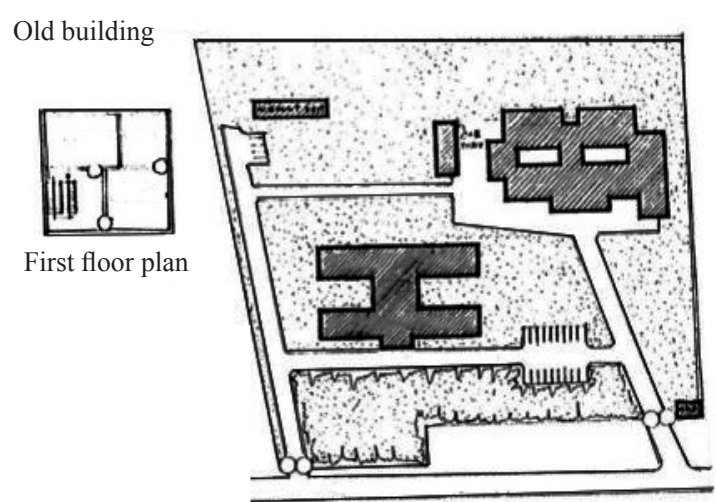

Site plan

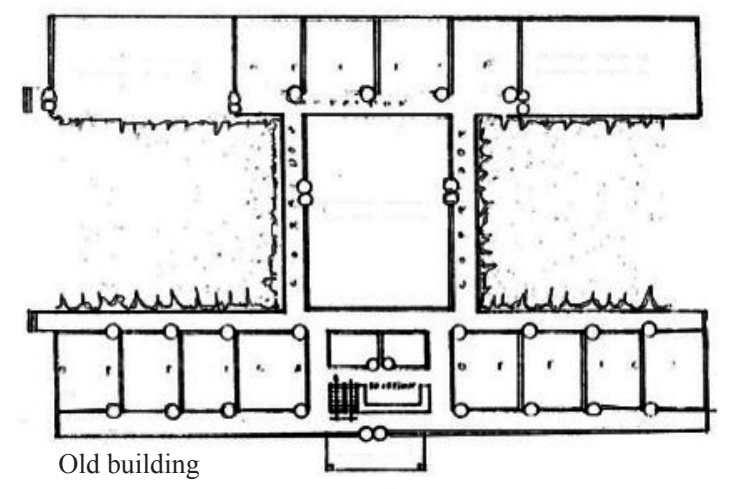

Ground floor plan

Figure 8. Old building plan, site plan and the state high court justice, Osogbo

\subsubsection{Symbolic meaning}

The two complexes i.e. the old and the new are appealing, simple and impressive. It shows formality and conveys the impression of a building for law and justice.

\subsubsection{Space pattern}

The old building consists of a car porch for the judge, a large reception/enquiry room to assist people, administrative offices and a stair at the reception to connect the judge to the judges' chamber and library. The structures consist of three courtrooms; the central courtroom is a double volume, while the others are not. The new complex, on the other hand, is designed in a courtyard pattern, where the ground floor contains offices, other administrative functions and a library. The upper floor contains thee chief judge's courtroom, chambers, courtrooms.

\subsubsection{Circulation patterns}

The entrance to both the new and old building is well pronounced with reception/enquiry to direct movement. There were good circulation patterns in the court building. The judges and the staffs' circulation are separated from that of the public. 

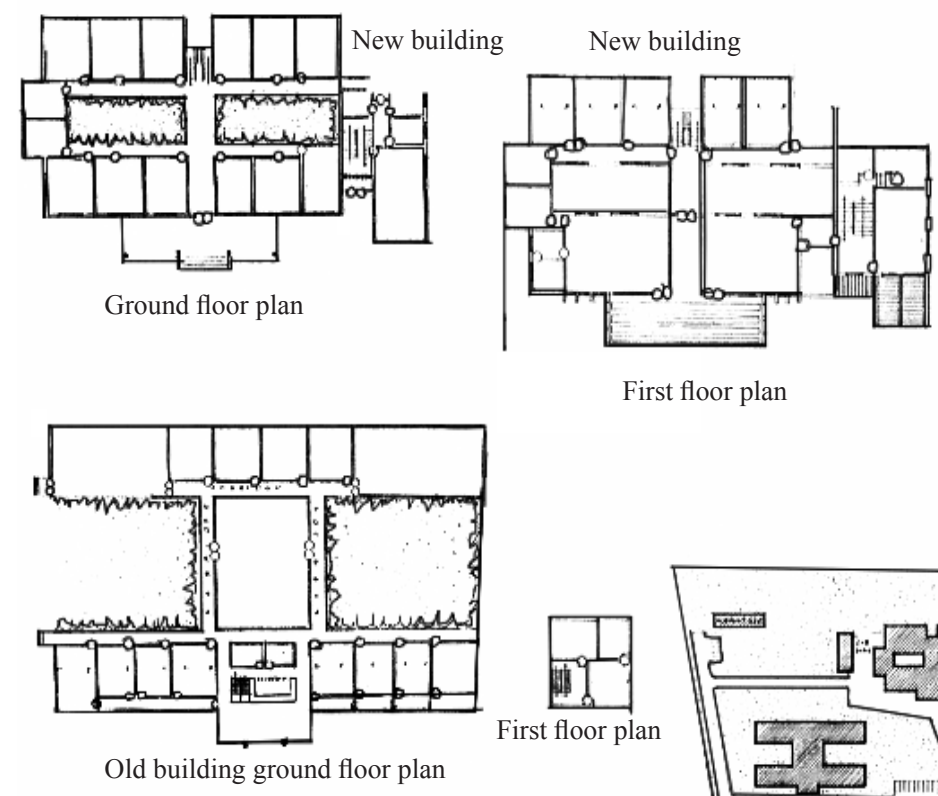

First floor plan

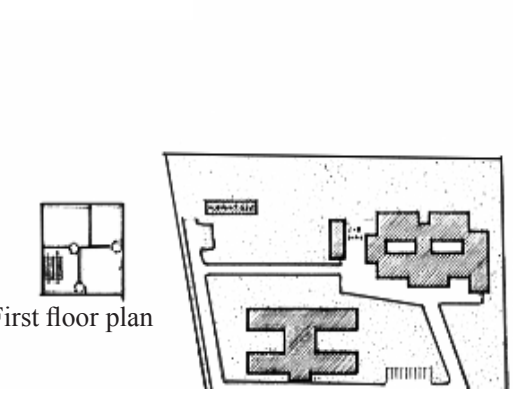

Figure 9. The old and new building plan, site plan and the state high court justice, Osogbo

\subsubsection{Courtroom arrangement}

The courtroom has well defined entrances for different categories of court participants. One significant element of the courtroom is the use of transparent glass so that the observer can directly observe the proceedings. Speakers are also installed in the ceiling to aid audio quality. The two courtrooms are double volume in terms of height and there is a sharp separation of different categories of participants in the courtrooms. Figure 10(a), illustrated the judge's conference room while Figure 10(b) shows the spectators sitting area. Figure 10(c) illustrates the statue of blindfolded women with sword and weight on each hand while Figure 10(d) shows the courtyard arrangement with the corridor linking various offices.

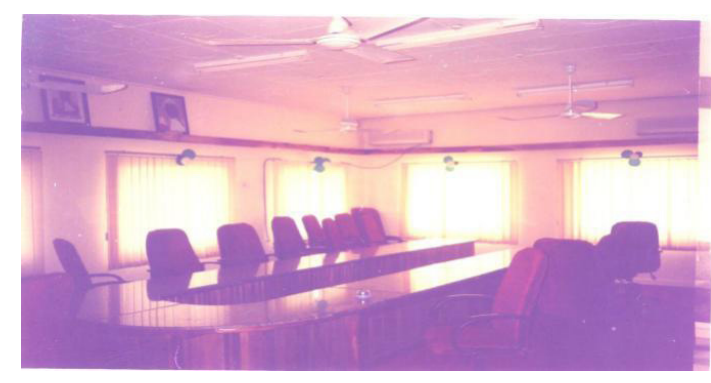

(a) Judge's conference room

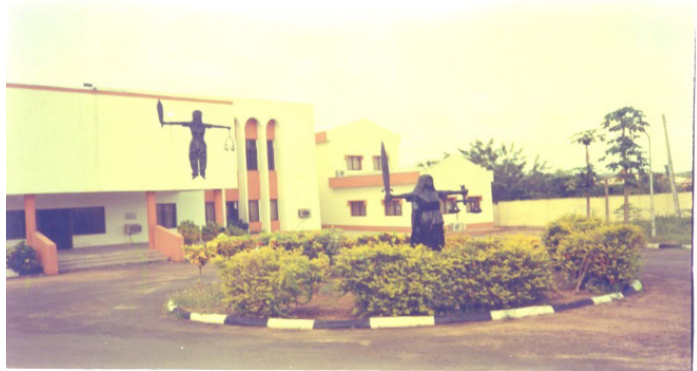

(c) Statue of a blindfolded women with sword and weight on each hand

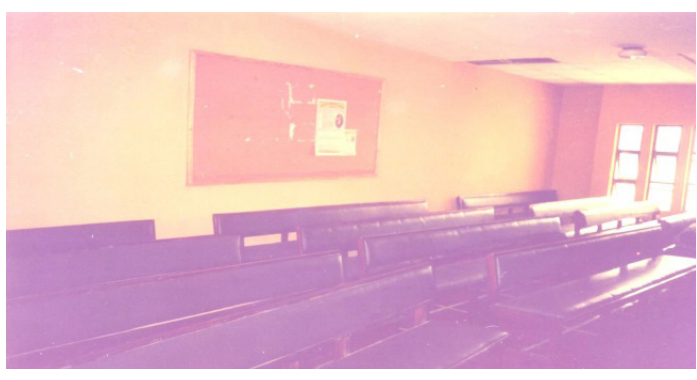

(b) Spectators sitting area

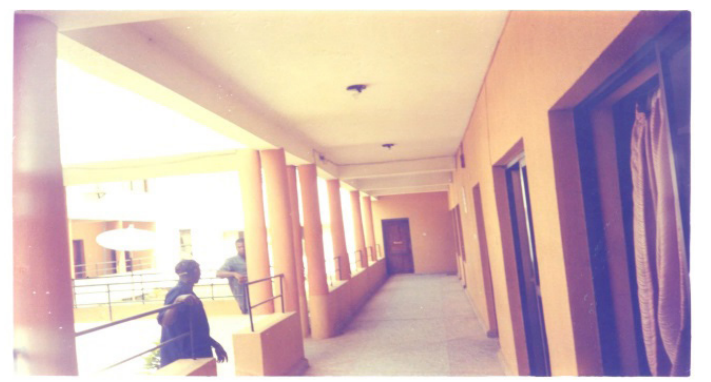

(d) Courtyard arrangement with a corridor linking various offices

Figure 10. Illustrated the judge's conference room, the spectators sitting area, the statue of blindfolded women, and the courtyard arrangement 


\subsection{Case study four: The high court of justice, Ogun State}

The building was completed in 1987 and was located at Isabo Road, Abeokuta in Ogun state. The court complex comprises of six high courtrooms and five magistrate courtrooms. The complex houses the high court of Abeokuta, magistrate court, library, conference rooms, administrative offices restaurant and cell rooms. Figure 12(a) shows a unit of the courthouse while Figure 12(b) shows Isabo Road linking the buildings.

\subsubsection{Site planning}

Both the high court and magistrate court complexes are separated with Isabo Road. There was no attempt to articulate a good site plan. The piecemeal approach was used to develop an individual building as opposed to a holistic approach, although the parking spaces are adequate and well laid out. There is no pedestrian circulation. The signboard was used to indicate the direction to various departments. The building was not well articulated to give natural direction (see Figure 11).

\subsubsection{Symbolic meaning}

The complex does not convey the symbolic meaning of a courthouse, but it has a formal outlook. The front elevation has nothing to suggest that it is a courthouse.

\subsubsection{Space patterns}

As stated above, the high court and magistrate court are separated with existing roads. The high court comprises of six high courtrooms together with the administrative spaces, registry probates registry, library, restaurant, cell rooms, and account sections while the magistrate section has five magistrate courtrooms, cell rooms and car parks (see Figure 11).

\subsubsection{Circulation pattern}

There is a clear separation in the judge circulation and that of the general public. The judges have their corridor, which takes them to their chamber and courtroom without crossing the public circulation. There are some obvious problems with the circulation pattern of the building because the main entrance is not visible, and this makes it difficult for visitors to find their way easily into various departments. A horizontal circulation system is used for the courtrooms, being a bungalow structure (see Figure 11).

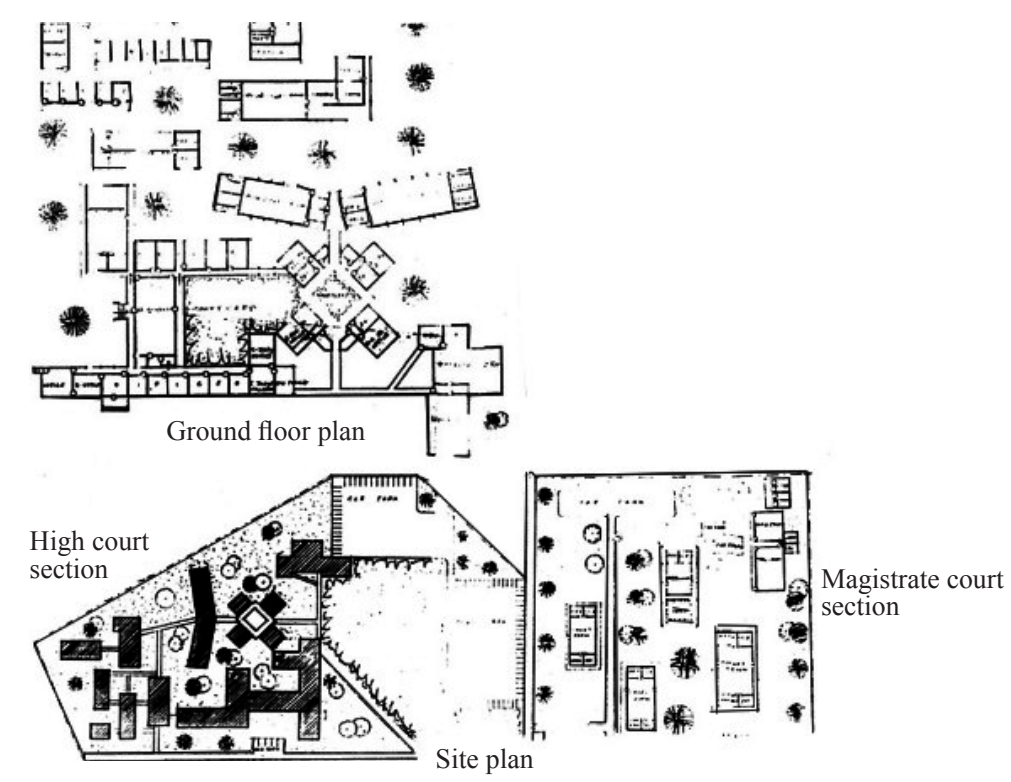

Figure 11. Building plan, site plan and the high court of justice, Ogun State 


\subsubsection{Courtroom arrangement}

The courtrooms arrangements are adequate, well lighted, and cross-ventilated, with a height of double volume.

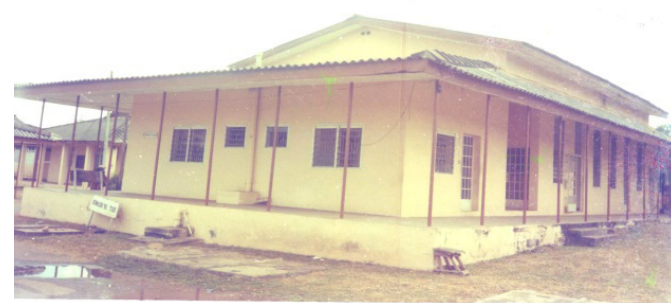

(a) Courthouse unit

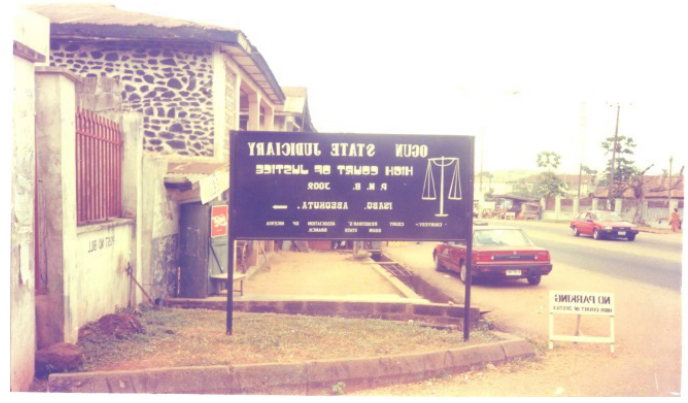

(b) Isabo Road linking the buildings

Figure 12. Court building external views and road linking the buildings

\subsection{Case study five: Ile-Ife high court complex, Osun State}

The building was completed in the year 1991 it was located along the Ife-Ibadan Express Road and opposite the Obafemi Awolowo University Ile-Ife. The court complex comprises of three high courtrooms, four magistrate courtrooms, juvenile courtroom,tribunal courtroom, principal registrar's office, registry, magistrate registry, library and other administrative offices.

\subsubsection{Site planning}

The site planning is inadequate and the parking is insufficient and not well articulated. There are no separate parking areas for the judges. The pedestrian work way is not well articulated (see Figure 13).

\subsubsection{Symbolic meaning}

The court complex is appealing for its simplicity. The architect seems to have done a good job with the massing. Despite its simplicity, it is still impressive and conveys the meaning of a formal building. It conveys the impressions of building for law and justice.

\subsubsection{Space pattern}

Corridors and courtyard link the spaces. These are for easy circulation into various spaces. The administrative offices are separated from the courtrooms. The judge chamber and library are on the first floor. The basement floor has two magistrate courtrooms, juvenile courtroom, tribunal courtroom and exhibit room (see Figure 13).

\subsubsection{Circulation pattern}

The circulation pattern is inadequate especially the separation of the circulation of the judge and the public. The judge and the public have the same entrance, which should otherwise be separated. The long corridor enhances good circulation around the courtroom (see Figure 13). 


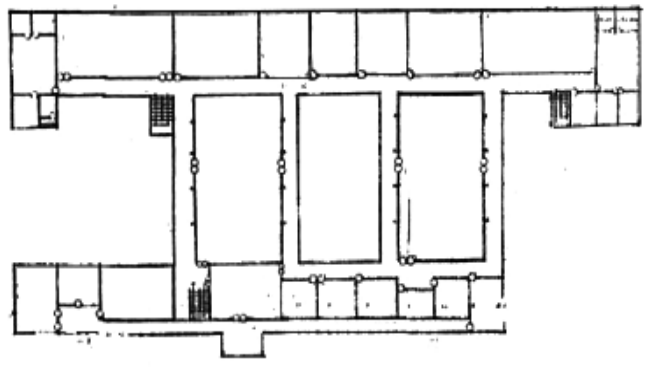

Ground floor plan

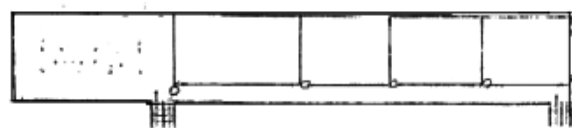

Site plan

Figure 13. Building plan, site plan and the Ile-Ife High Court Complex

\subsubsection{Courtroom arrangement}

The courtroom's arrangement; especially for the high courtroom 1 and 2 are adequate in terms of the position of docks, witness box, bench, clerk's desk and lawyers seating. These courtrooms are double volume. Magistrates' courtrooms were not adequately arranged. Figure 14(a) shows the statue and the building, and Figure 14(b) illustrates the sitting arrangement. Furthermore, Figure 14(c) shows the approach view of the building while Figure 14(d) shows the siting arrangement from another side.

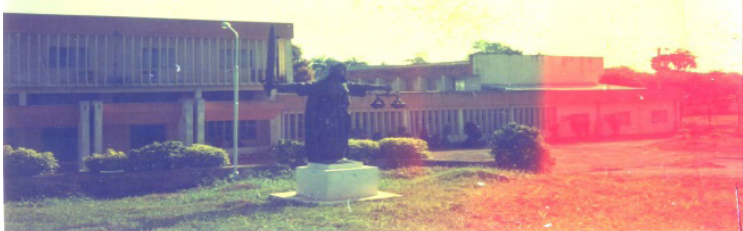

(a) Statue and building

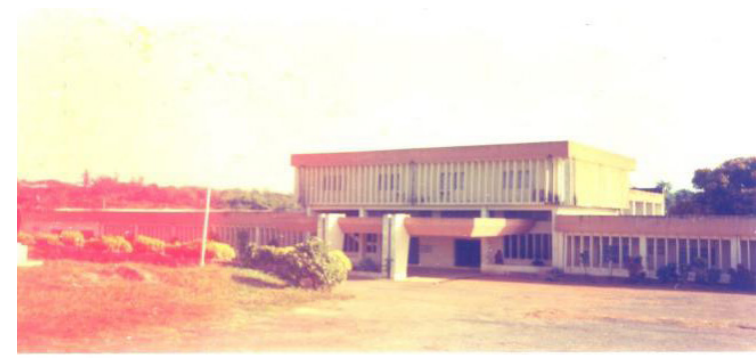

(c) Approach view of the building

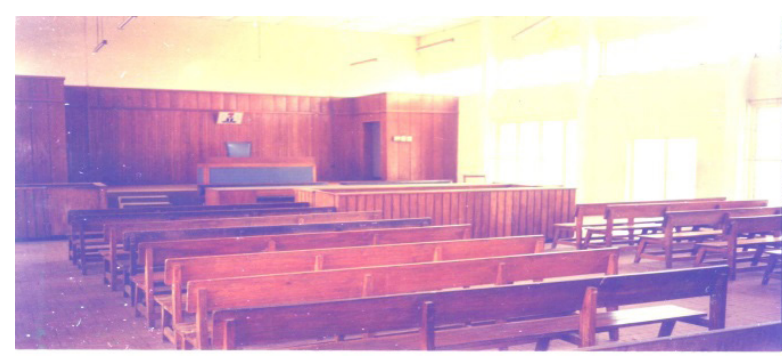

(b) Sitting arrangement

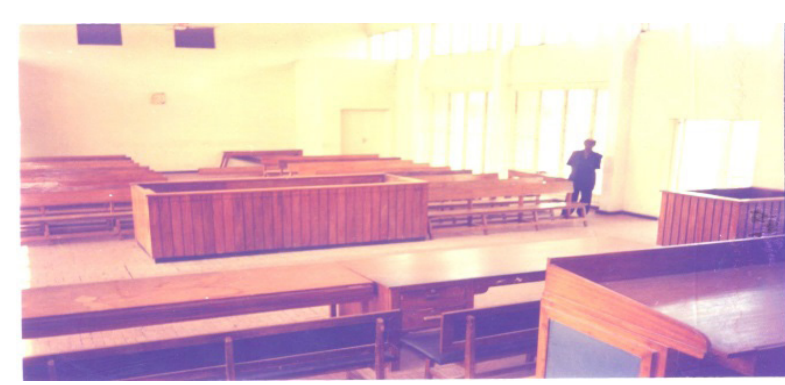

(d) Sitting arrangement from a different side

Figure 14. Courtroom internal arrangements and external features 


\subsection{General observations}

It is pertinent to review the role of the five high courts understudy to find out their performance according to users' requirement, physical dimensions,environment needs and ability to proffer a workable solution for the design of a high court. All high courts have included all the necessary facilities in their designs such as administrative, revenue, litigation, courts and accounts department. It is worth mentioning that the high court complex at Ile-Ife seems to relegate the administrative department to the background. This should not have been the case as the others are important as well. Without them, the courts cannot function properly. Thus, it is necessary to give them a more deserved prominence.

Similarly, the high court seems to lay too much emphasis on mechanical ventilation instead of the proper natural lighting of the courts. It is important to stress the need for natural ventilation in future high courts design since mechanical devices are prone to failure due to unavailability of spare parts and inadequate maintenance and services. The circulation pattern within the high courts is not flexible and direct enough to allow any visitor to locate their destination without being directed. This is a very important factor that needs to be taken care of in the design of high courts. Since all high courts are busy throughout the day, not many people will have the time to show the direction to newcomers. The planning should allow for sensational cases, and the role of the pressmen should be adequately defined in the courtroom. This is important to be able to curb their excessive.

It is necessary that designers of high courts take a cursory look at the shortcoming to improve. The general issues which must be carefully handled in every court design include functional planning, multiple circulations and public's convenience. The courthouse is expected to give a feeling of grandeur, strength and human transcendence. However, for any courthouse design to be successful, it must take into consideration the peculiarity of its location, the people it serves, and its importance to society. Only then it can be functional and fully serve the needs of the users and the society at large.

\section{Data analysis and research findings}

\subsection{Questionnaire administration}

All units of the high court were administered the questionnaires that cover five study areas, as shown in Table 1.

Table 1. Total questionnaire administered in the five studies areas

\begin{tabular}{ccccc}
\hline Index number & Units & Distributed questionnaires & Recovered questionnaires & $\begin{array}{c}\text { Percentage of the } \\
\text { recovered questionnaire }\end{array}$ \\
\hline 1 & Administrative & 45 & 39 & 86.7 \\
2 & Registry & 45 & 38 & 84.4 \\
3 & Cash office & 45 & 36 & 80.0 \\
4 & Courtrooms & 85 & 66 & 77.6 \\
5 & Library/Archive & 35 & 34 & 97.1 \\
6 & Others & 35 & 30 & 85.7 \\
& Total & 290 & 243 & $83.8 \%$ \\
\hline
\end{tabular}

Source: Authors field survey, 2018

Fair responses were acquired from all the high courts visited. The total number of questionnaires distributed were 290 and 243 were recovered, which equivalent to $83.8 \%$.

\subsection{Primary data analysis}

The data collected were subjected to statistical analysis for interpretation and inferences to be drawn. The statistical 
analysis provides tables, percentages were used for simple statistical description.

\subsection{Security and spatial organization indicators}

Some variables were used in the administration of the questionnaire. These variables were identified to have been used to determine the security and spatial organisation of some court building in Nigeria. All the high court staff and other participants that were administered with the questionnaire were asked to rate these variables as either (i) Satisfied, (ii) Just satisfied, (iii) Dissatisfied, (iv) More Dissatisfied, and (v) Very much Dissatisfied. Every respondent was instructed to choose a rating for each of the 15 listed variables. To analyse the data collected, each of the ratings is assigned a weight value as indicated below.

The weighted value for each factor was obtained by calculating the summation of weighted value (SWV) for each question. This was achieved by the summation of the product of the number of responses to each rating to a question and the respective weight value. This can be mathematically expressed as follows:

$$
S W V=\sum_{i=1}^{n} P i V i
$$

Where SWV is the summation of the weighted value of each of the 15 questions, Pi is the number of respondents choosing a particular rating $i$ and is the weight assigned to rating 1.

Where: SWV $=$ Total weight value

$\mathrm{N}=$ Total number of respondents

$\mathrm{P}=$ Number of respondents rating an attribute $\mathrm{i}$;

$\mathrm{Vi}=$ Weight assigned to attribute $\mathrm{i}$.

For example, the Summation of Weighted Value (SWV) is calculated for communication and spatial pattern within the courtroom for the staff of the high court of Justice Ibadan as a variable. Thus: $30 \times 5+20 \times 4+5 \times 3+5 \times 2+0$ $\times 1=255$. This is the process used for all 15 indicators in all five high courts studied, as shown in Table 2. From the analysis of the variables' rating of the five high courts, the staff responses in all studied area confirmed the validation of the indicators because it almost follows each other according to the orders of importance. However, Table 3 shows the combined rating from the staff and other high court users.

The results show that the high courts in the study area provided good characteristics in area communication and spatial pattern within the courtroom, environmental cleanliness, structural fitness, adequacy of pedestrian circulation, an acoustic system in the courtroom, court building layout, and space pattern, with SWV value of 255, 235, 225, 215, 215, 210, and 205 respectively. Meanwhile, the study areas are deficient in the areas of pollution control, adequate parking space, circulation pattern, natural lighting, symbolic meaning/visual form of the court building, adequate security, accessibility with other department and present of privacy, with SWV value of 185, 175, 175, 168, 170, 170 and 160 respectively which are low in quality and are not adequate. Similarly, in respect of the computation of security and spatial organisation indicators of the area, seven out of 15 variables had SWV above 200. It shows that users' perception of the overall court area is on the negative side on eight factors. This result implied that the architectural design and management of the courthouse in the study area need to consider some basic Security and Spatial Organization Indicators requirements such as pollution control, adequate parking space, circulation pattern, natural lighting, symbolic meaning/visual form of the court building, adequate security, accessibility with other department and present of privacy among others. This is important in determining court building quality and well-being of the users in the study area. The inference of this is that architects and other building professional engaged in the implementation, redevelopment, restructuring and upgrading of the existing court building, and planning and designing of a new one should involve suitable design principles in conceiving court building that meets users need and level of quality. 
Table 2. Security and spatial organisation in the court building: Indicators rated by the staff of the High Court of Justice, Ibadan

\begin{tabular}{|c|c|c|c|c|c|c|c|c|c|}
\hline \multirow{2}{*}{$\mathrm{S} / \mathrm{N}$} & \multirow{2}{*}{ Indicators } & Ratings & $\mathrm{i}$ & ii & iii & iv & $\mathrm{v}$ & $\mathrm{N}$ & \multirow{2}{*}{ SWV } \\
\hline & & Weight value & 5 & 4 & 3 & 2 & 1 & & \\
\hline 1 & Communication and spatial pattern within the courtroom & & 150 & 80 & 15 & 10 & 0 & 60 & 255 \\
\hline 2 & Environmental cleanliness & & 150 & 40 & 30 & 10 & 5 & 60 & 235 \\
\hline 3 & Structural fitness & & 100 & 80 & 30 & 10 & 5 & 60 & 225 \\
\hline 4 & Adequacy of pedestrian circulation & & 100 & 60 & 30 & 20 & 5 & 60 & 215 \\
\hline 5 & The acoustic system in the courtroom & & 100 & 60 & 30 & 20 & 5 & 60 & 215 \\
\hline 6 & Court building layout & & 100 & 60 & 30 & 10 & 10 & 60 & 210 \\
\hline 7 & Space pattern & & 125 & 20 & 30 & 20 & 10 & 60 & 205 \\
\hline 8 & Pollution control & & 50 & 60 & 45 & 20 & 10 & 60 & 185 \\
\hline 9 & Adequate parking space & & 50 & 40 & 45 & 30 & 10 & 60 & 175 \\
\hline 10 & Circulation pattern & & 50 & 60 & 30 & 20 & 15 & 60 & 175 \\
\hline 11 & Natural lighting & & 45 & 44 & 42 & 22 & 15 & 60 & 168 \\
\hline 12 & Symbolic meaning/visual form of the court building & & 50 & 40 & 45 & 20 & 15 & 60 & 170 \\
\hline 13 & Adequate security & & 50 & 40 & 45 & 20 & 15 & 60 & 170 \\
\hline 14 & Accessibility with other departments & & 50 & 40 & 45 & 20 & 5 & 60 & 160 \\
\hline 15 & Present of privacy & & 25 & 20 & 45 & 30 & 20 & 60 & 140 \\
\hline
\end{tabular}

Source: Authors field survey, 2018

Table 3. Security and spatial organisation in court building: Indicators in the study areas (Total responses from all the High Court visited)

\begin{tabular}{|c|c|c|c|c|c|c|c|c|c|}
\hline \multirow{2}{*}{$\mathrm{S} / \mathrm{N}$} & \multirow{2}{*}{ Indicators } & Ratings & $\mathrm{i}$ & ii & iii & iv & $\mathrm{v}$ & $\mathrm{N}$ & \multirow{2}{*}{ SWV } \\
\hline & & Weight value & 5 & 4 & 3 & 2 & 1 & & \\
\hline 1 & Environmental cleanliness & & 495 & 292 & 135 & 40 & 6 & 243 & 968 \\
\hline 2 & Communication and spatial pattern within the courtroom & & 475 & 296 & 105 & 64 & 7 & 243 & 947 \\
\hline 3 & Structural fitness & & 415 & 320 & 111 & 66 & 23 & 243 & 935 \\
\hline 4 & Space pattern & & 425 & 216 & 150 & 66 & 21 & 243 & 878 \\
\hline 6 & Court building layout & & 395 & 248 & 138 & 70 & 21 & 243 & 872 \\
\hline 5 & Adequate parking space & & 480 & 156 & 126 & 76 & 28 & 243 & 866 \\
\hline 7 & Accessibility with other departments & & 380 & 252 & 132 & 60 & 30 & 243 & 854 \\
\hline 8 & Pollution control & & 325 & 216 & 183 & 82 & 22 & 243 & 828 \\
\hline 9 & Symbolic meaning/visual form of the court building & & 370 & 188 & 120 & 92 & 36 & 243 & 806 \\
\hline 10 & Circulation pattern & & 280 & 252 & 162 & 82 & 29 & 243 & 805 \\
\hline 11 & Natural lighting & & 275 & 256 & 159 & 84 & 31 & 243 & 805 \\
\hline 12 & Adequacy of pedestrian circulation & & 335 & 232 & 123 & 72 & 41 & 243 & 803 \\
\hline 13 & The acoustic system in the courtroom & & 295 & 196 & 135 & 98 & 41 & 243 & 765 \\
\hline 14 & Present of privacy & & 245 & 224 & 162 & 90 & 39 & 243 & 760 \\
\hline 15 & Adequate security & & 210 & 204 & 186 & 86 & 45 & 243 & 731 \\
\hline
\end{tabular}

Source: Authors field survey, 2018

\subsection{An assessment of the security and spatial organization of selected court buildings}

The staffs and other participants of these high courts were asked to assess the security and spatial organisation of their various court buildings using the 15 indicators earlier listed. 


\subsection{Adequate security}

Staff and other participants of the various court complex were asked to rate the level of satisfaction of adequate security in their complex. The variable used and their corresponding rating were, Satisfied-5, Just Satisfied-4, Dissatisfied-3, More dissatisfied-2, and Very Much Dissatisfied-1. Total weighted value (TWV) is then calculated by the summation of values gotten from the multiplication of the number of responses for each rating and the respective weighted values as calculated as shown in Table 4.

Table 4. Level of adequate security in the court complexes

\begin{tabular}{|c|c|c|c|c|c|c|c|c|c|c|c|c|}
\hline \multirow{2}{*}{$\mathrm{S} / \mathrm{N}$} & \multirow{2}{*}{ High Courts } & \multicolumn{2}{|c|}{ Satisfied } & \multicolumn{2}{|c|}{ Just Satisfied } & \multicolumn{2}{|c|}{ Dissatisfied } & \multicolumn{2}{|c|}{$\begin{array}{c}\text { More } \\
\text { Dissatisfied }\end{array}$} & \multicolumn{2}{|c|}{$\begin{array}{l}\text { Very much } \\
\text { Dissatisfied }\end{array}$} & \multirow{2}{*}{ TWV } \\
\hline & & 5 & $\%$ & 4 & $\%$ & 3 & $\%$ & 2 & $\%$ & 1 & $\%$ & \\
\hline 1 & The High Court of Justice, Ibadan & 10 & 16.67 & 10 & 16.67 & 15 & 24.59 & 10 & 16.67 & 15 & 24.59 & 170 \\
\hline 2 & Ikeja High Court Complex & 5 & 7.81 & 9 & 14.06 & 20 & 31.25 & 15 & 23.44 & 20 & 31.25 & 171 \\
\hline 3 & State High Court of Justice Osogbo & 14 & 25.45 & 17 & 30.90 & 12 & 21.81 & 5 & 9.09 & 7 & 12.72 & 191 \\
\hline 4 & High Court of Justice, Ogun State & 8 & 18.60 & 8 & 16.60 & 10 & 23.25 & 7 & 16.28 & 10 & 23.25 & 126 \\
\hline 5 & IIe-Ife High Court of Justice Osun State & 5 & 15.15 & 7 & 21.12 & 5 & 15.13 & 6 & 10.91 & 10 & 18.18 & 90 \\
\hline
\end{tabular}

Source: Authors field survey, 2018

From Table 4, the summation weighted values are 170 for Ibadan, 171 for Ikeja, and 191 for Osogbo. This shows that IIe-Ife has the least security network while Osogbo has the highest security. Also, from the table, 20 respondents representing 33.33\%, 14 respondents representing 23.3\%, 31 respondents representing 56.36\%, 16 respondents representing $37.20 \%$ and lastly 12 respondents representing 36.36\% in Ibadan, Ikeja, Osogbo, Abeokuta and IIe-Ife are just satisfied with the level of adequate security in their various complex. It is only in Osogbo that level of adequacy of security was higher with $56.36 \%$ rating, while Ikeja has the least security of $23.3 \%$ respondents were satisfied while $76.7 \%$ were dissatisfied with their security. The reason was that the security was planned and effectively designed for Osogbo High Court while that of Ikeja High Court was not well planned because of the land constrained in Lagos State.

\subsection{Circulation pattern}

Court building involves a lot of people coming in and out of the complex. Therefore, for safety and security reason, these people require a separate circulation route. The circulations have to be simple, straightforward, ensure public convenience and avoid confusion. For these reasons, the circulation pattern is important for the location of various functions and departments in the court complex. Therefore, a court complex where members of the public constantly stop to ask for direction is sure of a poorly planned circulation pattern. The respondents were asked to rate the circulation pattern and routes in their court complex in order of Satisfied-5: Just Satisfied-4: Dissatisfied-3, More Dissatisfied-2, and Very Much Dissatisfied-1. The total weighted value was then calculated by the summation of values gotten from the multiplication of the number of responses for each rating and the respective weighted values are as shown in Table 5. 
Table 5. Level of circulation pattern in the court complexes

\begin{tabular}{|c|c|c|c|c|c|c|c|c|c|c|c|c|}
\hline \multirow{2}{*}{$\mathrm{S} / \mathrm{N}$} & \multirow{2}{*}{ High Courts } & \multicolumn{2}{|c|}{ Satisfied } & \multicolumn{2}{|c|}{ Just Satisfied } & \multicolumn{2}{|c|}{ Dissatisfied } & \multicolumn{2}{|c|}{$\begin{array}{c}\text { More } \\
\text { Dissatisfied }\end{array}$} & \multicolumn{2}{|c|}{$\begin{array}{l}\text { Very much } \\
\text { Dissatisfied }\end{array}$} & \multirow[t]{2}{*}{ TWV } \\
\hline & & 5 & $\%$ & 4 & $\%$ & 3 & $\%$ & 2 & $\%$ & 1 & $\%$ & \\
\hline 1 & The High Court of Justice, Ibadan & 10 & 16.67 & 15 & 24.59 & 10 & 16.67 & 10 & 16.67 & 15 & 24.59 & 175 \\
\hline 2 & Ikeja High Court Complex & 10 & 15.63 & 15 & 23.44 & 19 & 29.67 & 10 & 15.63 & 10 & 15.63 & 197 \\
\hline 3 & The State High Court of Justice Osogbo & 25 & 45.45 & 20 & 36.36 & 10 & 18.18 & 5 & 9.09 & 0 & 10.10 & 12 \\
\hline 4 & High Court of Justice, Ogun State & 5 & 11.63 & 5 & 11.63 & 15 & 34.88 & 10 & 23.28 & 8 & 0.0 & 90 \\
\hline 5 & IIe-Ife High Court of Justice Osun State & 6 & 18.8 & 8 & 24.24 & 8 & 24.24 & 6 & 18.18 & 5 & 15.15 & 103 \\
\hline
\end{tabular}

Source: Authors field survey, 2018

From the Table 5, the responses from High Court of Justice Ibadan shows that 25 respondents representing $41.67 \%$ are just satisfied with circulation pattern while others include: $39.06 \%$ of Ikeja High Court, $81.81 \%$ of the State High Court, Osogbo, 23.26\% of the High Court of Justice, Ogun State and $42.42 \%$ of IIe-Ife High Court. From these statistics, the circulation pattern in the State High Court Osogbo is the best while that of Ogun State is the worst with $76.74 \%$ very much dissatisfied with the circulation pattern, followed by Ikeja with $60.91 \%$ dissatisfied with the system.

\subsection{Levels of communication and spatial pattern within the court complexes}

The staffs and other court participants in all the five court complexes studied were asked to assess the communication and spatial pattern in the courtrooms with their jurisdictions having in mind the four types of communication in a courtroom which are visibility, audio, movement of people and document transfer. The rates and total weighted values were done as earlier stated above. The summary is given in the table below.

Table 6. Level of communication and spatial pattern within the court complexes

\begin{tabular}{|c|c|c|c|c|c|c|c|c|c|c|c|c|}
\hline \multirow{2}{*}{$\mathrm{S} / \mathrm{N}$} & \multirow{2}{*}{ High Courts } & \multicolumn{2}{|c|}{ Satisfied } & \multicolumn{2}{|c|}{ Just Satisfied } & \multicolumn{2}{|c|}{ Dissatisfied } & \multicolumn{2}{|c|}{$\begin{array}{c}\text { More } \\
\text { Dissatisfied }\end{array}$} & \multicolumn{2}{|c|}{$\begin{array}{l}\text { Very much } \\
\text { Dissatisfied }\end{array}$} & \multirow{2}{*}{ TWV } \\
\hline & & 5 & $\%$ & 4 & $\%$ & 3 & $\%$ & 2 & $\%$ & 1 & $\%$ & \\
\hline 1 & The High Court of Justice, Ibadan & 30 & 50.00 & 20 & 33.33 & 5 & 8.33 & 5 & 8.33 & 0 & 0.00 & 255 \\
\hline 2 & Ikeja High Court Complex & 10 & 15.63 & 10 & 15.63 & 15 & 23.44 & 14 & 21.88 & 15 & 23.44 & 175 \\
\hline 3 & The State High Court of Justice Osogbo & 25 & 45.45 & 20 & 36.26 & 5 & 9.1 & 5 & 9.1 & 0 & 0.00 & 230 \\
\hline 4 & High Court of Justice, Ogun State & 18 & 41.86 & 17 & 39.53 & 5 & 11.63 & 3 & 6.98 & 0 & 0.00 & 179 \\
\hline 5 & IIe-Ife High Court of Justice Osun State & 12 & 36.36 & 7 & 21.21 & 5 & 15.15 & 5 & 15.15 & 4 & 12.12 & 117 \\
\hline
\end{tabular}

Source: Authors field survey, 2018

From the Table 6, the respondent from the High Court, Ibadan shows that 50 respondents representing 83.33 are satisfied and just satisfied with the communication and spatial pattern within the courtroom, along with $31.35 \%$, $81.82 \%, 81.82 \%$, and $57.58 \%$ of respondents from Ikeja, Osogbo, Abeokuta and IIe-Ife High Court. Ibadan, Osogbo and Ogun States have over $80 \%$ respondent dissatisfied with the courtroom communication and spatial pattern, while $68.85 \%$ and $42.42 \%$ of respondents from Ikeja and IIe-Ife dissatisfied with the pattern. Each person should be spatially related to every other person in a courtroom in other to have a smooth session. The four types of communication and the units' space requirement are required to provide the basis for a courtroom plan which the designer must follow strictly to achieve a better result. 


\subsection{Space pattern (separation/location grouping of spaces) in court complex}

The space pattern is required to be articulated in order to have a distinct design in a court complex, which will help in designing functional court building with a good visual image. To achieve this; there is a need to separate and group some departments in order to improve the communication and movement of people. The staffs and other court participants of the various high courts were asked to assess these court complexes with the level of satisfaction of space pattern in their respective court building. The table below shows the levels of satisfaction.

Table 7. Space pattern within the court complexes

\begin{tabular}{|c|c|c|c|c|c|c|c|c|c|c|c|c|}
\hline \multirow{2}{*}{$\mathrm{S} / \mathrm{N}$} & \multirow{2}{*}{ High Courts } & \multicolumn{2}{|c|}{ Satisfied } & \multicolumn{2}{|c|}{ Just Satisfied } & \multicolumn{2}{|c|}{ Dissatisfied } & \multicolumn{2}{|c|}{$\begin{array}{c}\text { More } \\
\text { Dissatisfied }\end{array}$} & \multicolumn{2}{|c|}{$\begin{array}{l}\text { Very much } \\
\text { Dissatisfied }\end{array}$} & \multirow{2}{*}{ TWV } \\
\hline & & 5 & $\%$ & 4 & $\%$ & 3 & $\%$ & 2 & $\%$ & 1 & $\%$ & \\
\hline 1 & The High Court of Justice, Ibadan & 25 & 41.67 & 5 & 8.33 & 10 & 16.67 & 10 & 16.67 & 10 & 16.67 & 255 \\
\hline 2 & Ikeja High Court Complex & 15 & 23.44 & 14 & 21.86 & 15 & 23.44 & 9 & 14.06 & 11 & 17.19 & 205 \\
\hline 3 & The State High Court of Justice Osogbo & 25 & 45.45 & 20 & 36.36 & 10 & 18.18 & 0 & 0.00 & 0 & 0.00 & 230 \\
\hline 4 & High Court of Justice, Ogun State & 10 & 23.26 & 8 & 18.60 & 10 & 23.26 & 10 & 23.26 & 5 & 11.63 & 1237 \\
\hline 5 & IIe-Ife High Court of Justice Osun State & 10 & 30.30 & 7 & 21.21 & 5 & 15.15 & 4 & 12.12 & 7 & 21.21 & 108 \\
\hline
\end{tabular}

Source: Authors field survey, 2018

From the Table 7 above, 30 respondents which corresponded to $50 \%$ of the total people administered the questionnaires to Ibadan are satisfied with the separation and location grouping of various departments while $40 \%$ of respondents are dissatisfied with the system. For Ikeja, 29 respondents which are $45.31 \%$ out of the total respondents are satisfied while 54.69 are dissatisfied with the design. The State High Court Osogbo has the highest respondents that are satisfied, representing $81.84 \%$ while only $18.18 \%$ were dissatisfied. The High Court of Justice, Ogun State and IIe-Ife High Court complex Osun State have 18 and 17 respondents satisfied representing 41.8\% and 51\% respectively.

\subsection{Acoustic system within the various court complexes}

Acoustics is the law governing sound vibration and the method of transfer from the source to the receiver. Acoustic has various fields like electro-acoustic, engineering acoustics and architectural acoustics. In this project, more emphasis is laid on architectural acoustics. Architectural acoustics is defined as the behaviour of sound waves and the laws that enable one to design and construct room which will adequately carry sound from the source to the listener [31]. It should not be relegated to the position of an afterthought and considering the broad requirement earlier in the design process which will help these difficulties. The choice of the site is not decided without a thorough noise and vibration study. These observations emphasise the importance of acoustic consideration in court building whose use is connected with sound. Hence, the Architect should be conscious of the effect of their design decision in terms of shape, size, construction method and materials. There should be two major objectives in the courtrooms acoustics. These are namely to attenuate or exclude unwanted sound (noise) from the room and to provide the desired acoustical within the room. The latter objectives had been simplified by the extensive use of engineering acoustic. The 'formal' is what is referred to as sound insulation. Sound insulation is the act or process of cutting away unwanted sound (noise) from particular space by the interposition some non-conductors (i.e. sound insulate material with sound-reducing capacity). There are three ways to eliminate unwanted sounds these are: Eliminated the noise at the source by enclosing the source, Modify the path along with which the sound energy is transmitted and provide the receiver with some form of protection. Good acoustics and acoustic privacy are required in a courtroom. Therefore special precaution must be taken to enable participants to hear clearly without stain. The walls and ceiling must be cladded with Celotex which must penetrate the suspended ceiling and sealed against the structural slab. Air movement must be planned to inhibit the transfer of sound, pipes, as duct should be specially insulated. The floors of the courtroom should be carpeted. The respondents were asked 
to assess the acoustics system in their various courtrooms with the level of satisfaction and calculation is done as earlier stated.

Table 8. Acoustics system within the court complexes

\begin{tabular}{|c|c|c|c|c|c|c|c|c|c|c|c|c|}
\hline \multirow{2}{*}{$\mathrm{S} / \mathrm{N}$} & \multirow{2}{*}{ High Courts } & \multicolumn{2}{|c|}{ Satisfied } & \multicolumn{2}{|c|}{ Just Satisfied } & \multicolumn{2}{|c|}{ Dissatisfied } & \multicolumn{2}{|c|}{$\begin{array}{c}\text { More } \\
\text { Dissatisfied }\end{array}$} & \multicolumn{2}{|c|}{$\begin{array}{l}\text { Very much } \\
\text { Dissatisfied }\end{array}$} & \multirow{2}{*}{ TWV } \\
\hline & & 5 & $\%$ & 4 & $\%$ & 3 & $\%$ & 2 & $\%$ & 1 & $\%$ & \\
\hline 1 & The High Court of Justice, Ibadan & 20 & 33.33 & 15 & 25 & 10 & 16.67 & 10 & 16.67 & 5 & 8.33 & 215 \\
\hline 2 & Ikeja High Court Complex & 10 & 15.63 & 10 & 15.63 & 15 & 23.44 & 19 & 29.29 & 10 & 15.63 & 183 \\
\hline 3 & The State High Court of Justice Osogbo & 15 & 27.27 & 10 & 1.18 & 5 & 9.09 & 8 & 14.55 & 7 & 12.73 & 153 \\
\hline 4 & High Court of Justice, Ogun State & 8 & 18.60 & 8 & 18.60 & 7 & 16.28 & 7 & 16.28 & 13 & 30.23 & 120 \\
\hline 5 & IIe-Ife High Court of Justice Osun State & 6 & 18.18 & 6 & 18.18 & 4 & 12.12 & 5 & 15.15 & 12 & 36.36 & 88 \\
\hline
\end{tabular}

Source: Authors field survey, 2018

From the Table 8, it shows that High Court, Ibadan with 35 respondents representing 58.33 are satisfied with the acoustics system while Ikeja, Osogbo, Abeokuta and IIe-Ife had 20, 25, 16, 12 respondents respectively representing $31.25 \%, 45.45 \%, 37.21 \%$ and $36.36 \%$ respectively of the respondent satisfied with the acoustic system in the courtroom. From this discovery, it shows that only High Court of Justice, Ibadan took the acoustic system seriously with the used of Timber panels which were cladded on the wall, carpeting on the floor and the use of Celotex for the ceiling and glass fibre/sealant for windows.

\subsection{Pollution control (noise and air)}

Noise and air pollution are one of the most important factors that have to be considered in the location of a high court. Noise and air pollution are always high in the area where there is heavy traffic and in an industrial area. Therefore, courtrooms should be located far enough from heavy traffic and industrial area. To avoid these hindrances in the new design study was also carried out on the existing high court building. The rating is as shown in Table 9 below.

Table 9. Noise and air pollution within the court complexes

\begin{tabular}{|c|c|c|c|c|c|c|c|c|c|c|c|c|}
\hline \multirow{2}{*}{$\mathrm{S} / \mathrm{N}$} & \multirow{2}{*}{ High Court } & \multicolumn{2}{|c|}{ Satisfied } & \multicolumn{2}{|c|}{ Just Satisfied } & \multicolumn{2}{|c|}{ Dissatisfied } & \multicolumn{2}{|c|}{$\begin{array}{c}\text { More } \\
\text { Dissatisfied }\end{array}$} & \multicolumn{2}{|c|}{$\begin{array}{l}\text { Very much } \\
\text { Dissatisfied }\end{array}$} & \multirow[t]{2}{*}{ TWV } \\
\hline & & 5 & $\%$ & 4 & $\%$ & 3 & $\%$ & 2 & $\%$ & 1 & $\%$ & \\
\hline 1 & The High Court of Justice, Ibadan & 10 & 16.67 & 15 & 25 & 15 & 25 & 10 & 16.67 & 10 & 16.67 & 185 \\
\hline 2 & Ikeja High Court Complex & 9 & 14.96 & 10 & 15.63 & 20 & 31.25 & 15 & 23.44 & 10 & 15.63 & 185 \\
\hline 3 & The State High Court of Justice Osogbo & 25 & 45.45 & 15 & 27.27 & 10 & 18.18 & 5 & 9.09 & 5 & 9.09 & 230 \\
\hline 4 & High Court of Justice, Ogun State & 8 & 18.60 & 8 & 18.60 & 10 & 23.26 & 7 & 16.28 & 10 & 23.26 & 126 \\
\hline 5 & IIe-Ife High Court of Justice Osun State & 13 & 39.39 & 6 & 18.18 & 6 & 18.18 & 4 & 12.12 & 4 & 12.12 & 119 \\
\hline
\end{tabular}

Source: Authors field survey, 2018

From the Table 9, it shows that Ibadan with 25 respondents are satisfied, representing 41.67\% while 58.33 are dissatisfied with the noise and air pollution disturbing the court premises. Meanwhile, in Ikeja, Osogbo, Abeokuta and Ile-Ife, 19, 40, 16 and 19 respondents representing 29.69\%, 72.73\%, 37.21\%, and 57.58\% respectively are satisfied with the pollution controls. The high court Osogbo was located at the outskirt of Osogbo town and the distance of the High court to the main road is very far. Osogbo again has the highest respondents that are satisfied with the location of 
the court complex which has reduced noise and air pollution within their complex with $72.73 \%$ satisfied and $27.27 \%$ dissatisfied. Ikeja had the fewest respondents that are satisfied with the noise and air pollution in their complex with $29.69 \%$ while $70.31 \%$ representing 45 respondents dissatisfied with the pollution control. This is because the complex is located around a busy road and industrial zones, which constitute a major source of noise and air pollution.

\subsection{Adequacy of parking spaces}

The parking spaces in the court complexes have to be well design and be adequate. It must not be muddled up and should be sufficient. There is a need to separate the car park for the judges of the high court, staff and other court participants, for security reason and conveniences. The staffs and other respondents of the various high court building were asked to rate the adequacy and functionality of the parking spaces in order of satisfied, just satisfied, dissatisfied, more dissatisfied, very much dissatisfied. The calculation is done as previously describe and the summary is given in Table 10 below.

Table 10. Adequate parking space within the court complexes

\begin{tabular}{|c|c|c|c|c|c|c|c|c|c|c|c|c|}
\hline \multirow[t]{2}{*}{$\mathrm{S} / \mathrm{N}$} & \multirow{2}{*}{ High Court } & \multicolumn{2}{|c|}{ Satisfied } & \multicolumn{2}{|c|}{ Just Satisfied } & \multicolumn{2}{|c|}{ Dissatisfied } & \multicolumn{2}{|c|}{$\begin{array}{c}\text { More } \\
\text { Dissatisfied }\end{array}$} & \multicolumn{2}{|c|}{$\begin{array}{l}\text { Very much } \\
\text { Dissatisfied }\end{array}$} & \multirow[t]{2}{*}{ TWV } \\
\hline & & 5 & $\%$ & 4 & $\%$ & 3 & $\%$ & 2 & $\%$ & 1 & $\%$ & \\
\hline 1 & The High Court of Justice, Ibadan & 10 & 16.67 & 10 & 16.67 & 15 & 25 & 15 & 25 & 10 & 16.67 & 176 \\
\hline 2 & Ikeja High Court Complex & 9 & 14.06 & 10 & 15.63 & 15 & 23.44 & 15 & 23.44 & 15 & 23.44 & 175 \\
\hline 3 & The State High Court of Justice Osogbo & 40 & 72.73 & 10 & 18.18 & 0 & 9.09 & 0 & 0.00 & 0 & 0.00 & 295 \\
\hline 4 & High Court of Justice, Ogun State & 30 & 69.77 & 5 & 11.63 & 4 & 9.30 & 4 & 9.30 & 4 & 9.30 & 190 \\
\hline 5 & IIe-Ife High Court of Justice Osun State & 13 & 23.33 & 4 & 12.12 & 4 & 12.12 & 4 & 12.12 & 15 & 45.45 & 83 \\
\hline
\end{tabular}

Source: Authors field survey, 2018

Table 10 reveals that 20 respondents representing $33.33 \%$ are satisfied with the parking system in the high court of Justice Ibadan and forty respondents are dissatisfied with the design. The table also shows that 19, 50, 25 and 11 respondents representing $29.69 \%, 90.91 \%, 81.40 \%$ and $33.33 \%$ respectively are satisfied with the parking design in Ikeja, Osogbo, Abeokuta and Ile-Ife respectively. The State High Court of Justice Osogbo with 50 respondents representing $90.91 \%$ and the court of Justice Ogun State with 35 respondents representing $81.40 \%$ are the two high courts with good parking layout.

\section{Summary of findings}

Major findings from the analysis include the level of security and spatial organisation in some court building in Nigeria. As shown from the result obtained from the staff and other court participants according to the level of satisfaction as shown in Table 2, which shows the summation weighted value of all the indicators, its shows that (1) adequate security, (2) acoustics system, (3) privacy, (4) symbolic meaning/visual image, (5) circulation pattern, and (6) Natural lighting are the major shortcomings facing the effectiveness of our high court premises. From the Table also, it reveals that most of our high courts' buildings are satisfactory in the area of environmental cleanliness, communication and spatial pattern structural fitness and space pattern in the court building complex. While some are satisfactory and some are dissatisfied in pollution control, building layout, parking space, pedestrian circulation and accessibility with other departments. From all indicators, as shown in the study, the state high court of justice Osogbo is distinct and effective as it satisfies most of the respondent requirement. While the Ikeja High Court is the least as the indicators show that most respondents are dissatisfied with the complex in term of the security and spatial organisation of the design. From the study, it shows that the effectiveness of high court building depends on: Good spatial organisation within the 
court premises; Adequate security within the premises; Well-planned building layout; Good acoustics consideration for sensitive areas; adequate and effective parking space; good pedestrian circulation; the premises should be clean and attractive; effective communication and spatial pattern; it should avoid pollution (both noise and air pollution); the structure should have good visual form and should symbolise what a court should look like; and each department should be accessible to one another. The summary is as shown in Figure 15 below.

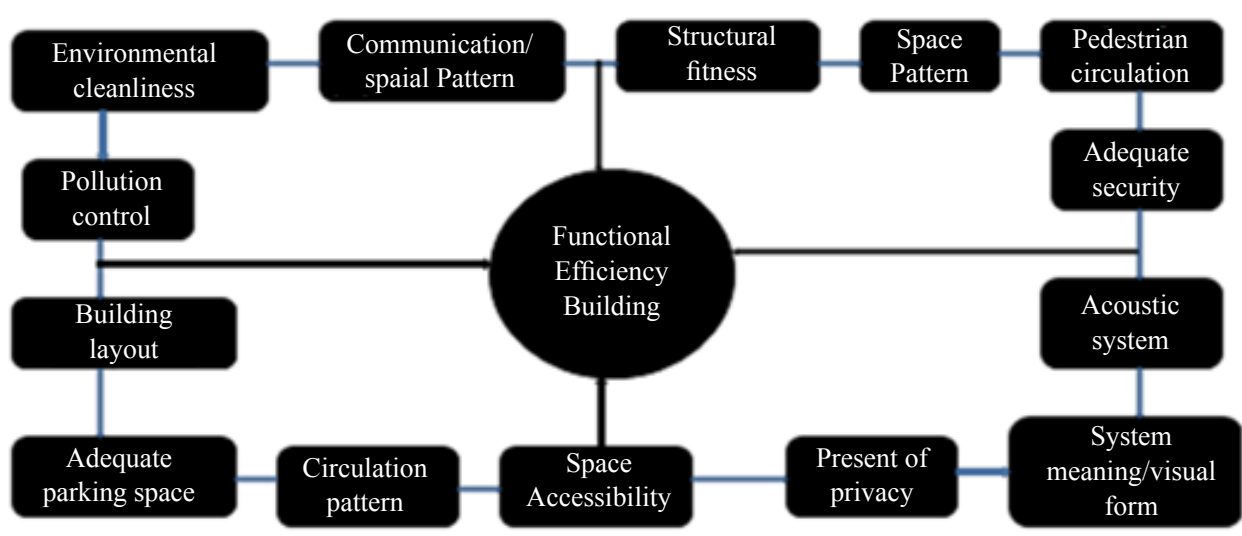

Figure 15. Identified factors influencing functional efficiency court buildings

\section{Security within the court building}

Circulation pattern within the court building for security personnel, judges and litigants' movement in courthouse present inefficient planning and design problems; this is because the manner armed security officers and litigants were brought into court under heavy guard is not conducive to an image of calm and even justice. Adequate courthouse security couples with a humane and unobtrusive environment require a proper separation of user's routes and the use of protective devices like alarms as well as closed-circuit television systems. The separation of traffic routes is very important, judges require maximum security in the courthouse to ensure their safety as well as enhance their composure and confidence during the administration of justices as well as attracting the confidence of the public. Apart from courtroom safety, judges require protection at the courthouse entrance from the aggrieved litigants and their relatives.

Public and prisoners' access should also be separated since it will be embarrassing for a prisoner to run away from his escort, and mix with the public and eventually escape. This may result in the infliction of bodily harm on members of the public during the process of forceful re-arresting of the prisoner. Therefore, the importance of maximum security cannot be overemphasised. It has a great impact on the administration of justice. Whatever form of courtroom layout adopted, it should be aimed at achieving maximum security and easy accessibility. The following guidelines help ensure maximum securities: judges should have direct access to the courtroom from their private areas and this access should be far from the dock; there should be direct access from the custody area to the dock; the witness box should be on the opposite side of the courtroom and the public on the other side. The judge should be on one side of the courtroom and the public on the other side and the law enforcement agents should have access to the area of the courtrooms; also, there should be separate and direct access for prisoners from custody to courtroom and dock area with the door leading to the dock opening from the courtroom; the prisoner entry to the court premises to be separated and lead directly to the public post. Figure 16 shows a typical circulation pattern within the court building for security personnel, judges and litigants' movement in the courthouse.

Private and public entrances and internal and external spaces need to be segregated. The illustrative diagram displays how the significant essential spaces are grouped on either side of the 'safe line'. Exceedingly segregated buildings for instance court buildings need additional vertical and horizontal circulation routes that impact greatly on building effectiveness. A fundamental part of enhancing efficiency is the use of control corridors on the private side. These corridors permit collective use by staff, judges and witnesses under the guide. For court buildings with amenities for jurors, there are additional secure outlines on the private area of the court building, guaranteeing the separation 
of judiciary from the jurors.

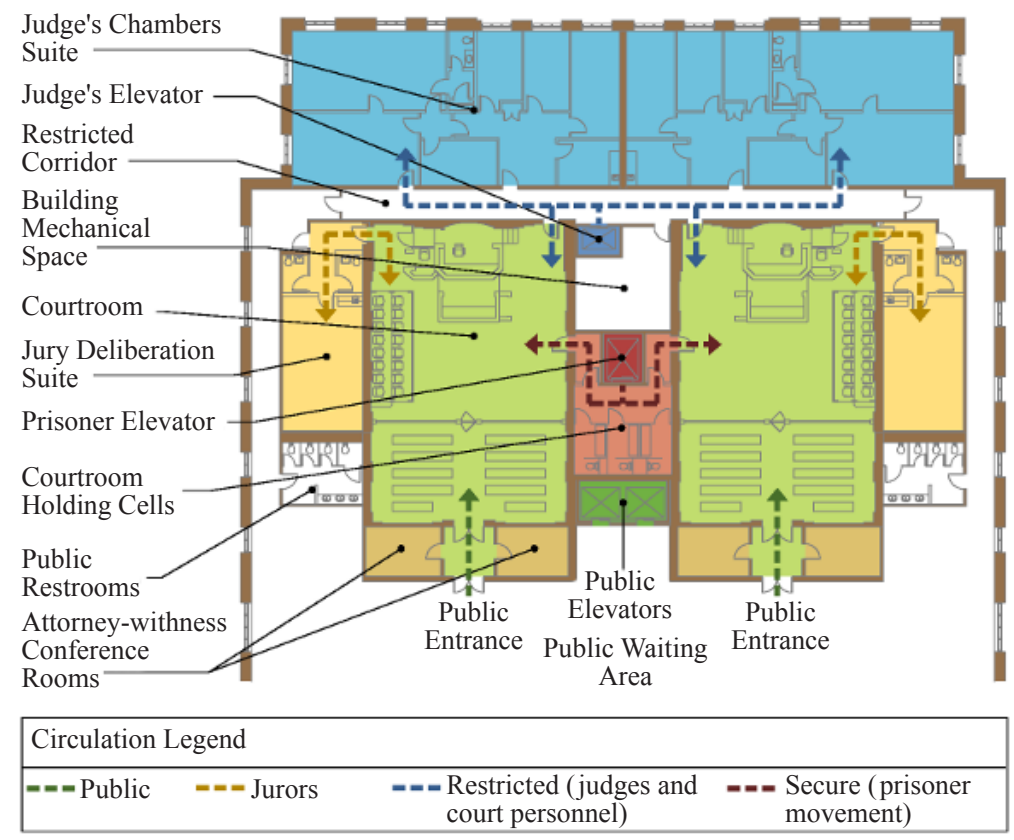

Figure 16. Typical circulation pattern within the court building for security personnel, judges and litigants' movement in the courthouse [32]

Figure 17 shows a characteristic of the courtroom layout and how the circulation pattern would link with each area. The emphasis of circulation pattern would predominately be within the public and hearing room areas.

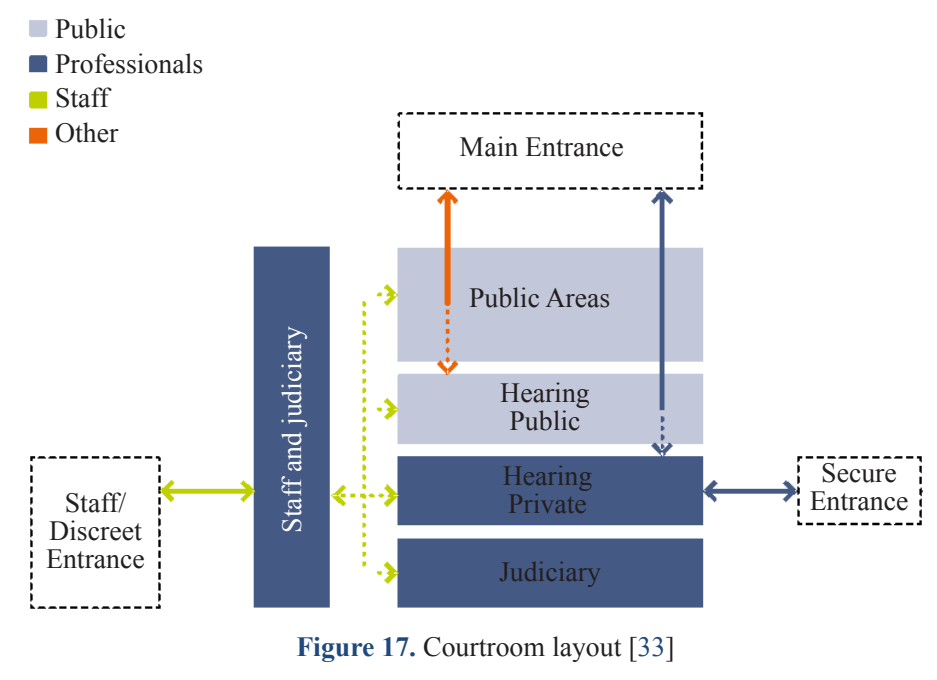

\section{Recommendations and suggestions}

Based on the findings in this study, the following recommendations were made concerning court buildings with high court complexes as the focus. In the planning of a courthouse, the architect should be involved right from the inception stage, and made to realise the intricacies of a court design and usage; the need to present a courthouse as a 
symbolic, sacred and official edifice must be emphasised in the design; arrangement of similar activities together in the design is very important as well as the strict adherence to restrictive circulatory channelling of the various court personnel; the need to adapt the design for other activities other than the court proceedings are also necessary; there is a need to provide or improve on the infrastructural facilities like erratic electrical telecommunication services, to mention few, so as to enhance functioning abilities of the courthouse personnel; more landscaping elements like shading trees, sculpture, should be incorporated into the site design criteria of the courthouse building, so as to increase public interest in them; and the use of modern materials is required in courthouse buildings to achieve excellence design with the reflection of functions, good technology and aesthetics. Courthouse layout must take circulation, security, solar radiation, the flexibility of design and stability into consideration to aid legal interaction between judges and the public as well as promoting the administrative image of the court and state in general.

\section{Conclusion}

This study assessed the security and spatial organisation problems in courthouses using the case studies method. Spatial problems identified are inadequate office spaces, circulation problem, misuse of available spaces, and poor arrangement of spaces. It also went further to analyse planning consideration for courthouse design with references to users, with consideration to circulation, security, lighting and ventilation, fire protectors and acoustic requirements in court buildings. A brief historical development was also done. The problems were analysed, and the solution to them was offered and proposals were put forward.

This study on high court building complexes in Nigeria was to achieve an architectural solution in the design of court buildings, which symbolises a high court building complex where the judicial function is been performed effectively. Efforts are equally made to ensure that the created spaces are interrelated in which everybody using the complex can experience comfort. Security of the judges and general security of the people using the complex should be taken into consideration during the planning stage. It is, however, pertinent to note that the importance of the high court buildings should be a masterpiece. The architects should make additional efforts, putting in enthusiasm and write up to create an edifice that is efficient, unique in its character, functional in its architectural context and create a sense of belonging to its users, which symbolise all that justice, should be. Finally, the study recommends a highly functional structure which touches on security and spatial organisation that forms a basic consideration in the courthouse. There is no doubt that the courthouse designed with these variables in mind will add more feather to the crown of Nigeria architectural glory, and most importantly, a symbolism to the Nigeria Legal System.

\section{Conflict of interests}

There is no conflict of interests associated with this publication and there is no financial fund for this work that can affect the research outcomes.

\section{References}

[1] Makinde OO. The spatial-security organisation of Nigeria court buildings: An assessment of selected court buildings and design for the high court, Ogbomoso. Unpublished M. Tech. Thesis Lautech. 2005. p. 1-150.

[2] United Nations. Handbook Special Edition. 1999.

[3] Mulcahy L. Architects of justice: The politics of courtroom design. Social Legal Studies. 2007; 16: 383. Available from: DOI: 10.1177/0964663907079765.

[4] Makinde OO. Spatial Organisation of High Court Buildings in South Western Nigeria. LAP LAMBERT Academic Publishing; 2013. Available from: https://www.morebooks.de/store/gb/book/spatial-organisation-of-high-courtbuildings-in-south-western-nigeria/isbn/978-3-659-30885-7 [Accessed 8th October 2020].

[5] Branco P. Considering a different model for the family and children courthouse building. Reflections on the portuguese experience. Oñati Socio-Legal Series. 2018; 8(3): 400-418. Available from: https://doi.org/10.35295/osls.iis1/0000- 
0000-0000-0940 [Accessed 10th October 2020].

[6] Holy B. Revised Standard New Edition Version (Exodus 23). 2020.

[7] Alaba A. The Community Court of Justice for ECOWAS Countries. Unpublished M.Sc. Thesis FUTA. 2001. p. 1-125.

[8] Whyte A, Karibi A. History and Sources of Nigerian Criminal Law. Published law series. Ibadan, Nigeria; 1993.

[9] Waltman J, Hollan K. The Political Role of law Courts in Modern Democracies. London: Macmillian press Ltd.; 1988.

[10] Gélinas F, et al. Architecture, rituals, and norms in civil procedure. Windsor Yearbook of Access to Justice. 2015; 32(2): 213-232. Available from: https://ojs.uwindsor.ca/ojs/leddy/index.php/WYAJ/article/download/4711/397 [Accessed 8th October 2020].

[11] Tunkun GI. International Law. Soviet Union: Moscow progress publishers; 1986.

[12] Redstone LG. Institutional Building: Architecture of the Controlled Environment. Mc. Graw Hill Book Company; 1980. p. 112-132.

[13] Omoleye BO, Eniola BO. Administration of Justice in Nigeria: Analysing the dominant legal ideology. Journal of Law and Conflict Resolution. 2018; 10(1): 1-8. Available from: DOI: 10.5897/JLCR2016.0242.

[14] Goodrich P. Visive powers: Colours, trees and genres of jurisdiction. Law and Humanities. 2008; 2(2): 213-231. Available from: https://www.researchgate.net/profile/Peter_Goodrich3YU/publication/263370239_Visive_Powers_ Colours_Trees_and_Genres_of_Jurisdiction/links/58f49ee7aca27289c21c8c92/Visive-Powers-Colours-Trees-and Genres-of-Jurisdiction.pdf [Accessed 8th October 2020].

[15] Branco P. Courthouses as spaces of recognition, functionality and access to law and justice: A portuguese reflection. Oñati Socio-legal Series. 2016; 6(3): 426-441. Available from: http://ssrn.com/abstract=2812699 [Accessed 8th October 2020].

[16] Lucien A. Staging and the imaginary institution of the judge. International Journal for the Semiotics of Law. 2010; 23(2): 185-206.

[17] Scheppele KL. Judges as architects. Yale Journal of Law \& the Humanities. 2012; 24(1): 345-396. Available from: http://digitalcommons.law.yale.edu/cgi/viewcontent.cgi?article=1391\&context=yjlh [Accessed 10 October 2020].

[18] Brigham J. Material Law: A Jurisprudence of What's Real. Philadelphia, PA: Temple University Press; 2009.

[19] Spaulding NW. The enclosure of justice. Courthouse architecture, due process, and the dead metaphor of trial. Yale Journal of Law \& the Humanities. 2012; 24(1): 101-133. Available from: http:/digitalcommons.law.yale.edu/cgi/ viewcontent.cgi?article $=1390 \&$ context $=y j$ lh [Accessed 8th October 2020].

[20] Branco P. Os Tribunais como Espaços de Reconhecimento, de Funcionalidade e de Acesso à Justiça [Courts as Spaces for Recognition, Functionality and Access to Justice]. Oporto: Vida Económica; 2015.

[21] Tutt O, Adler A. New Metric Handbook on Planning and Design Data. Wutterworth and company Publisher Limited; 1979.

[22] Bybee KJ. Judging in place: Architecture, design, and the operation of courts. Law \& Social Inquiry. 2012; 37(4): 1014-1028. Available from: http://dx.doi.org/10.1111/j.1747-4469.2012.01327.x [Accessed 8 October 2020].

[23] McNamara MJ. From tavern to the courthouse. Architecture \& Ritual in American Law. Baltimore, MD: The Johns Hopkins University Press; 2004. p. 1658-1860.

[24] Clark J. Reflection. Justice. Architecture Australia. 2009; 98(5). https://architectureau.com/articles/reflection-8/ [Accessed 7th October 2020].

[25] CEPEJ. Guidelines on the organization and accessibility of court premises. A document adopted by the CEPEJ at its 24th Plenary Meeting. Strasbourg; 2014. p. 11-12. Available from: https://rm.coe.int/16807482cb [Accessed 18th October 2020].

[26] Goltsman S. Recognizing children and families in the design of a children's court. Children's Environments. 1992; 9(1): $72-76$.

[27] Ngwa-Suh M. Facility Facelifts: How courthouses are accommodating children and youth. Children's Voice. 2006; 15(1): 29-31.

[28] Carmo RA. Nova Organização do Sistema Judiciário e a Jurisdição de Família e Menores. Revista do Ministério Público [Organization of the Judiciary and the Jurisdiction of family and minors. Public Prosecutor's Review]. 2014; 140: 9-32.

[29] Woodson E, Tillman B, Tillman P. Human Factor Design Handbook. Mc Graw Hill Book Co. the USA; 1992.

[30] Commaille, JO. espaço da justiça como questão política entre necessidades e desafios-uma abordagem de sociologia política do direito [Space of justice as a political issue between needs and challenges-an approach of political sociology of law]. In: P. Branco (ed.) Sociologia do(s) Espaço(s) da Justiça: Diálogos Interdisciplinares [Sociology of Justice Space(s): Interdisciplinary Dialogues]. Coimbra, Portugal: CES/Almedina; 2013. p. 21-35. 
[31] Calender JH. Time Savers Standards for Architectural Design. Mc Graw Hill books ompany; 1982. p. 680-699.

[32] Ruby A. The Courtroom Set: A Vital Part of Courthouse Planning. 2018. Available from: https://blog.fentress.com/ blog/the-courtroom-set-a-vital-part-of-courthouse-planning [Accessed 18th October 2020].

[33] Attrill K, Crosby J. Court and Tribunal Design Guide, 2019; Version1.1. HM Court \& Tribunal service (HMCTS). 2019. 